Recibido: marzo de 2018

Aprobado: mayo de 2018

DOI: https://doi.org/10.15332/rev.m.v15i0.2180

Bagdadi traditional Turkish construction in Mudanya, Turkey

Source: Elena Perria, 2017

\section{TIMBER STRUCTURAL TECHNIQUES FROM THE DAWN OF THE CIVILIZATION TO THE EXPANSION OF CITIES IN THE XIX CENTURY IN EUROPE AND ITS COLONIES}

\author{
Elena Perria - Institute of Building Construction and Timber Structures \\ Technische Universität Braunschweig - Germany
}

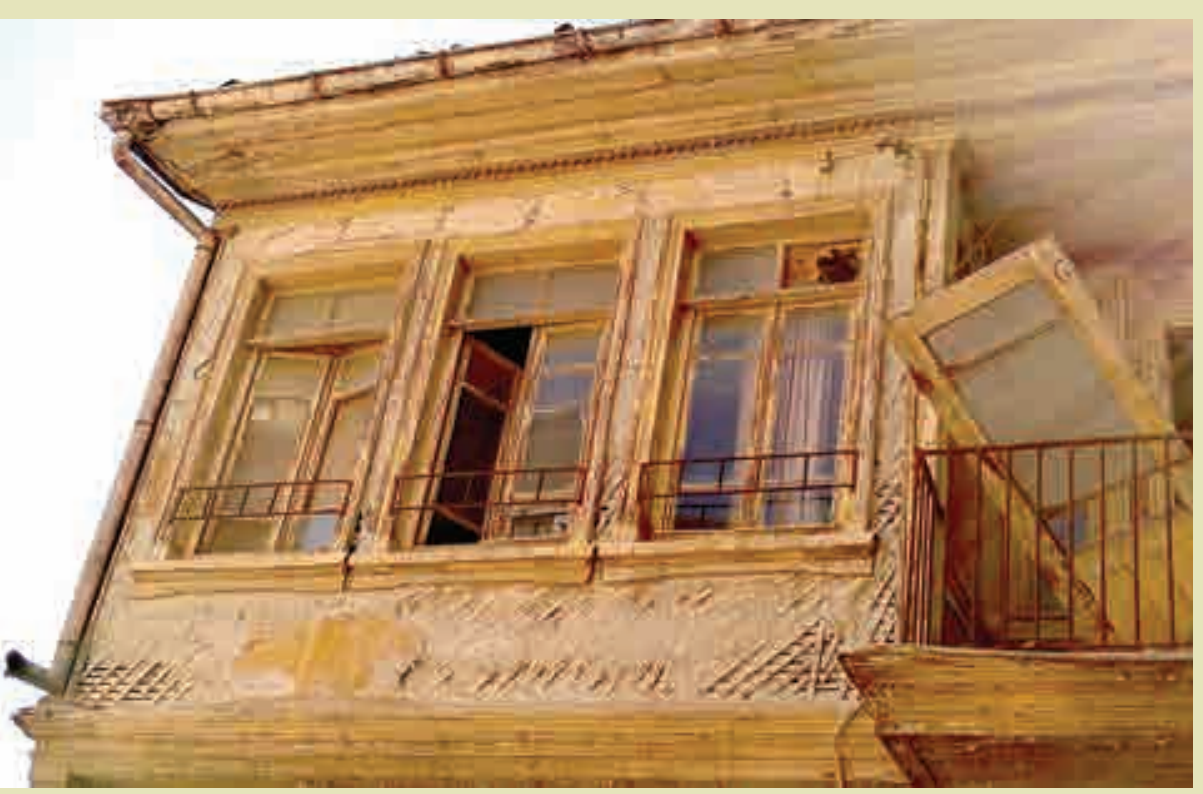

\section{ABSTRACT}

This paper is a general description of the state-of-the-art on the European and colonial building techniques found in wooden buildings that currently exist. The description of the use and diffusion of the wooden structures is made by a brief explanation of the relative structural systems, as well as the peculiarities of the elements that compose it, its operating principles, the points of weakness and the joints used. Thus, the English and German techniques of structural timber frameworks are described in detail. On the other hand, other structural techniques and their evolution are presented through a review of works and documents that describe them accurately.

\section{KEYWORDS}

Construction techniques, wood, Europe, colonies, structural systems. 


\section{TÉCNICAS ESTRUCTURALES EN MADERA DESDE LOS ALBORES DE LA CIVILIZACIÓN HASTA EL CRECIMIENTO DE LAS CIUDADES EUROPEAS $Y$ SUS COLONIAS EN EL SIGLO XIX}

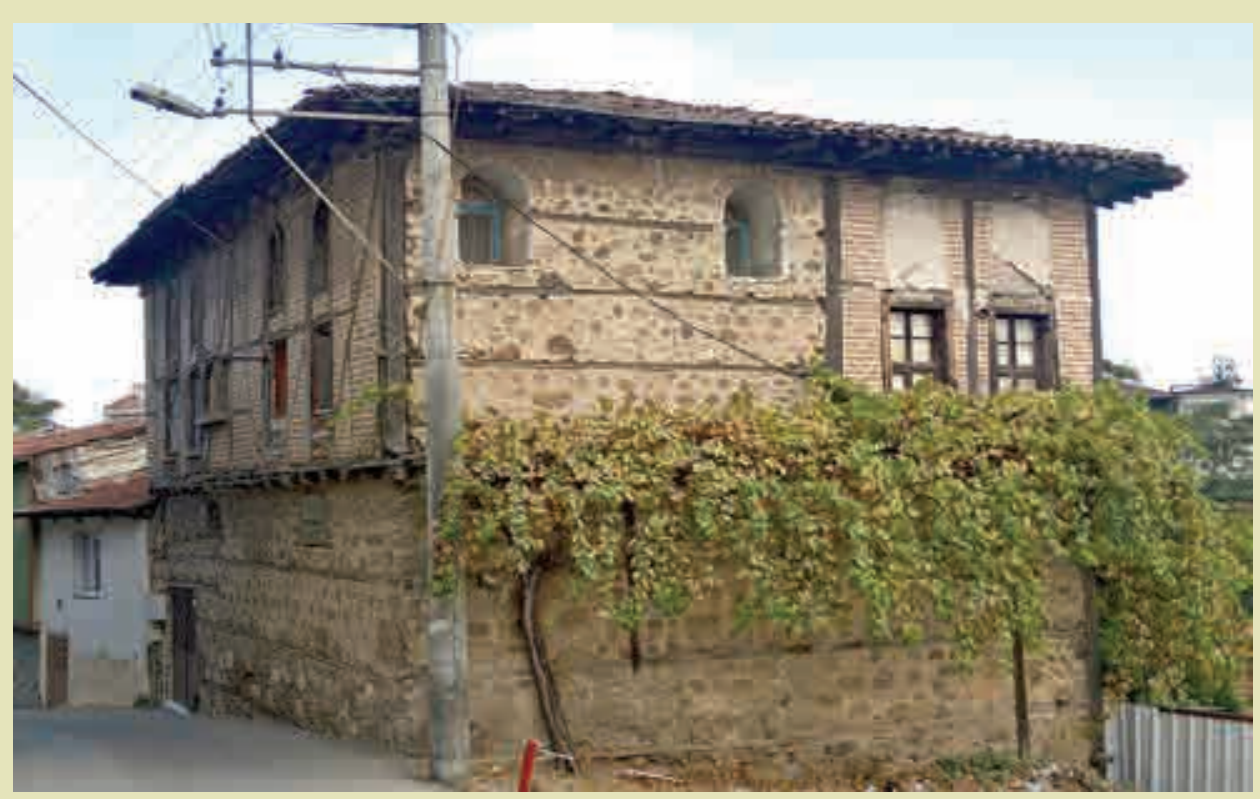

Hımış constructional technique on a TAQ technique basement in Mudanya, Turkey Source: Elena Perria, 2017.

\section{RESUMEN}

El presente documento es una descripción general del estado del arte sobre las técnicas constructivas europeas y coloniales, encontradas en edificaciones de madera que existen actualmente. La descripción del uso y la difusión de las estructuras de madera se realizan mediante una breve explicación de los relativos sistemas estructurales, así como las peculiaridades de los elementos que la componen, sus principios de funcionamiento, los puntos de debilidad y las uniones utilizadas. Así bien, las técnicas inglesas y alemanas de los entramados estructurales de madera se describen en detalle. Por otra parte, otras técnicas estructurales y su evolución se presentan mediante una revisión de trabajos y documentos que las describen con precisión.

\section{PALABRAS CLAVE}

Técnicas de construcción, madera, Europa, colonias, sistemas estructurales. 


\section{INTRODUCTION}

Since humanity learned to use tools for the first time, wood has been used for the creation of bridges, war machines, boats and shelters. Thus, the wood associated with stone, bricks, clay or earth, has been the oldest building material in most regions of the world, at least, since the human race began to build shelters in the dawn of the civilization. Therefore, the history, development and evolution of wooden structures is an extensive subject that includes material, climatic and social reasons, style trends, as well as technical updates under the principle of learning by doing (UWE, 2008).

Wood has been a resource with thousands of different species, easily available in areas with forests. Throughout the centuries, the consolidated tradition of solid wood construction led to an intensive and progressive use of these forests so the original wood was replaced by a secondary growth, that is, an availability of younger and smaller trees. This fashion of timber buildings produced at the time a shortage of this material of primary construction, with problems not only in terms of quantity but quality. In the sixteenth century, the lack of wood, coupled with the expansion of cities, also linked to a progressive increase in height in buildings and a new standardization in wood techniques, were a phenomenon that led to the evolution of new construction system with the available smaller structural timber components.

Later, modern timber constructional techniques evolved along the centuries under the working principles of (i) presence of structural timber elements with direct contact surfaces, (ii) transmission of compression and friction forces, (iii) organization of the structural organism as a closed structural "cage". Among the timber techniques, the half-timbered are the ones whose frame is intended to be left exposed, while the frame structures are generally all those in which the timber load-bearing frame is not visible. More, the log construction consists of superposed round logs laying horizontally, to form the load bearing walls. With the evolution of modern composite materials, the beginning of the era of contemporary structural techniques was signed; among them, the platform timber construction, prefabricated timber panels construction, and glulam structures (Langenbach, 2006).

For all developed systems, the connection plays first of all an important static role. Secondly, it has been engaged an evolution in style techniques over time. Depending on the entity of the stress in the structure and elements to join, the use of different geometric solutions for the connections was founded. The upgrade of the structural technique was accompanied with the evolution of always more efficient geometries corresponding to the specific load-carrying structural element and its stress. In the modern timber construction techniques, the woodworking connections with use of wooden nails and wedges, and sometimes reinforced with iron brackets and hand-forged nails are prevailing; on the other side, contemporary constructional techniques faced the introduction of metallic mechanical fasteners and steel joints. The oldest connections are fashioned in the structural elements itself in form of grooves, notches and sloping surfaces, which basic mechanism is the transmission of forces through the friction interaction among contact surfaces. In contemporary constructional techniques, the members are connected by steel plates or mechanical fasteners (nails, staples, screws, lag screws, dowels, bolts, ecc.) that joint mechanically the structural elements.

\section{ORIGIN OF MODERN TIMBER STRUCTURAL SYSTEMS}

The first vernacular wooden structures date back to the primeval man age, when the first shelters with circular plant where built. These first constructions were simple structures composed of a main load bearing structures with row wood set on the ground's level and covered with a roof of tree branches and leaves. This primitive structural system can be assimilated in the group called post constructions. 
The earliest evidence of the first significant constructional change is from I200 BC: the passage from the basic shelter to the pile foundation construction and the log construction marked in fact the further step for the development or modern structural techniques. The first pile foundation construction (Figure I) consisted of posts set into the ground. In the earlier evolution of the pile foundation construction the posts are driven into the ground onto stone pads or further wooden elements that distance the lower extremity of the wooden pole from the ground.

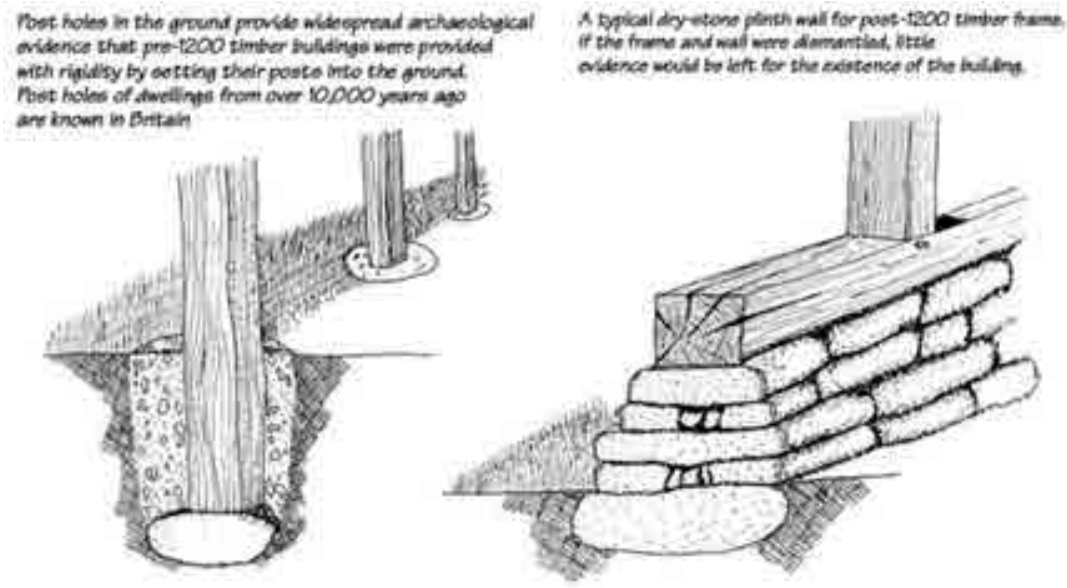

With the insertion of poles into the ground, both this systems provided buildings of a stable structure, but at costs of their longevity. In fact, because of the infiltration of the water from the ground, the wood is subjected to progressive decay until putrefaction. The durability of posts clamped into the ground is in fact around 20-30 years. Despite their problems in durability, the post construction and the pile foundation construction marked the basic principles of the modern halved and framed houses.

To avoid the manifested accelerated decay process of the wood, the construction gained further distance from the soil (Figure 2) with the introduction of a basement wall under the wooden piles. The next further passage that signed the introduction of the modern halftimber and frame construction happened when posts jointed into a sill beam on a basement wall replaced the piles. The new half-timber construction provided buildings of far greater longevity but required a higher level of technical competence to increase the stability of the building in height.

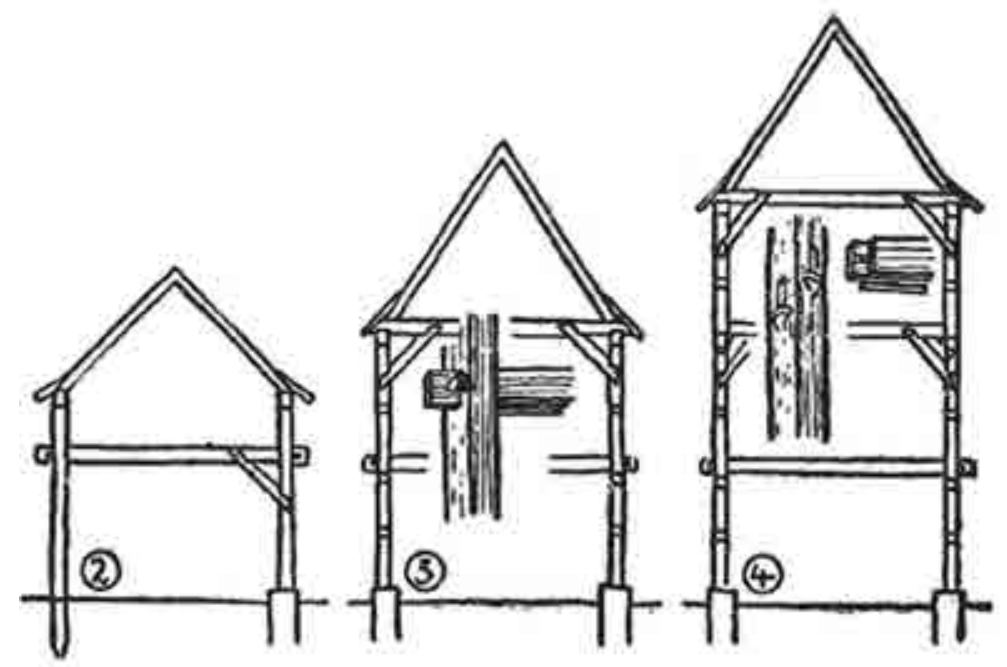

Figure I. The first pile foundation construction Source: Traditional Timber Framing, A Brief Introduction. University of the West of England, Bristol, 2008.
Figure 2. Evolution of the half-timber structure Source: Nebel, 1978 
Figure 3. Vitruvius' Opus Graticium in Hercolaneum, Neaples, Italy Source: By Kuznetsova Yulia, La Casa a Graticcio, Herculaneum - Own work, CC BY-SA 3.0 (https://commons.wikimedia.org/w/index. php?curid= 18227258)
In fact, joining the posts on a sill beam removed much of the buttressing support both along and across the building. The understanding of the structure allowed carpenters to evolve structural configurations with increasing stability. The first supporting framework bases on the principle of post and lintel framing, composed of horizontal and vertical loadbearing elements; this system was further enhanced by introduction of diagonal bracing in correspondence of the right-angle connections between sill beam and posts to reduce or prevent racking or lateral movements of the structure. This step was of great importance in the evolution of the constructional technique, for the resistance on-plane that the construction acquired.

\section{MODERN CONSTRUCTIONAL TECHNIQUES: BORN AND EXPANSION OF THE TECHNIQUES IN EUROPE AND AROUND THE WORLD}

The first vernacular post construction houses known as longhouses where erected in the $4500 \mathrm{BC}$. Around the $600 \mathrm{BC}$ the first roman timber vaulted bridges built by means of wooden ribs appeared, and developed along the whole Roman Empire era. In this context, the first known half-timber system was developed in Herculaneum (Naples) before the 79 BC. The system described by Vitruvius, called Opus Graticium, combines a timber frame with masonry infill (Figure 3). During the Roman Empire, more elaborated techniques like the joinery techniques called mortise and tennon, and triangulated roof structures were also introduced.

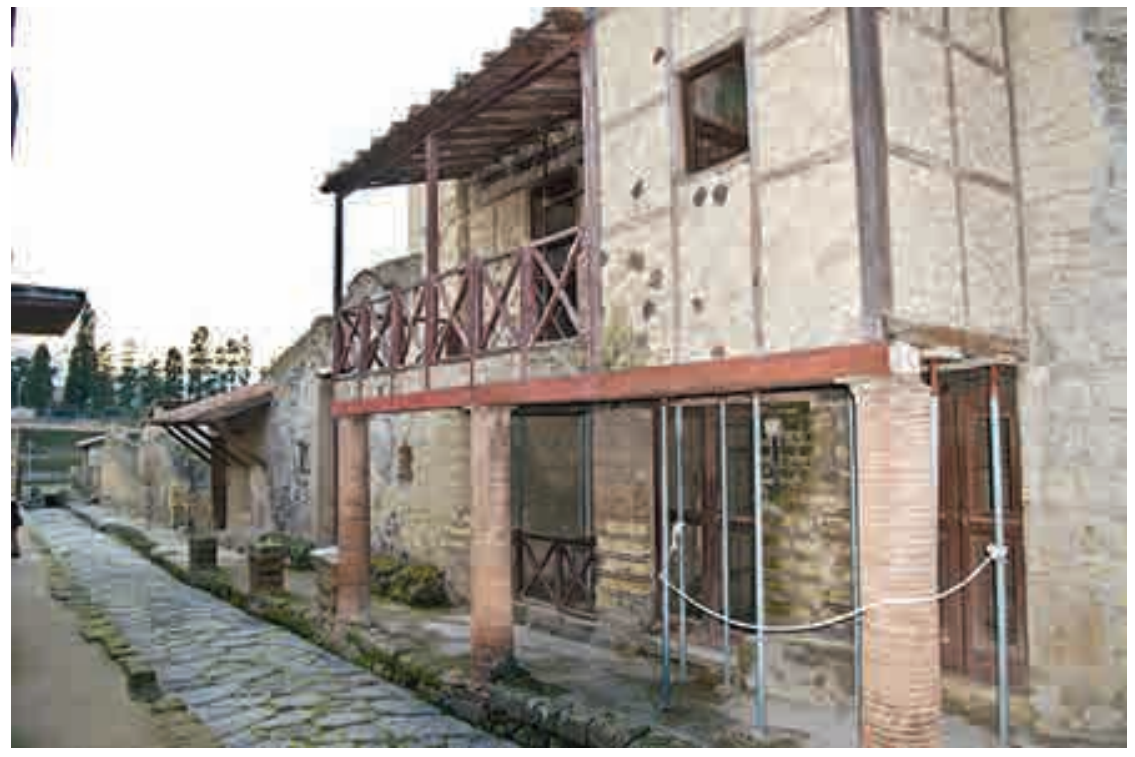

The half-timber constructions became widespread and known his highest diffusion near the end of the Middle Ages and evolved throughout Europe in many different national and regional stylistic and constructional differences. The half-timber structures took the name of edificios Pombalinos in Portugal, Casa Baraccata in Italy, Fachwerk in Germany, Lefkas island's Technique in Greece, Colombage in France, Bindingverk in Scandinavia, Half-timber in United Kingdom and entramado Mudejar Spain. During the Ottoman Empire in the middle-east, the wooden frame structures diffused also in India (Dhajji-dewari), Kashmir (TAQ) and Turkey (Hımış and Bagdadi construction).

After the colonial expansion, Spain, United Kingdom, and France, exported their national techniques all over the world. The integration of the western techniques with the indigenous ones brought to the implementation of the colonial systems with peculiar stylistic 
and constructive characteristics. From the lberian tradition, the "Sistema Colonial" was developed in southern America and Caribbean areas (Morcate, 1990).

Original from the English tradition, the Gingerbread houses were adapted in Haiti to the American environment; finally, the "Colombage pierroté" construction, derived from the French culture, acquired proportions, morphologic characters and construction materials that suit with the new location in Haiti (Langenbach, 20I0). Furthermore, the Germanic tradition was exported to Pennsylvania, North Carolina, Texas, Missouri and Wisconsin (Sobon, 2002). The Fachwerk structures were not intended to be built as the German constructional "aesthetical" finishing but under the same constructional concept. The half-timber constructional system was employed for the construction of economic buildings until the first half of the XIX century in most of the continental European regions, America and UK.

\section{ASIATIC AND SOUTHERN EUROPEAN EXAMPLES}

In India and Kashmir, the traditional timber-brick masonry (dhajji-dewari) construction is a brick-nogged timber frame construction that consists of burnt clay bricks filling in a framework of timber to create a patchwork of masonry, which is confined in small panels by the surrounding timber elements (Langenbach, 2013) (Figure 4).

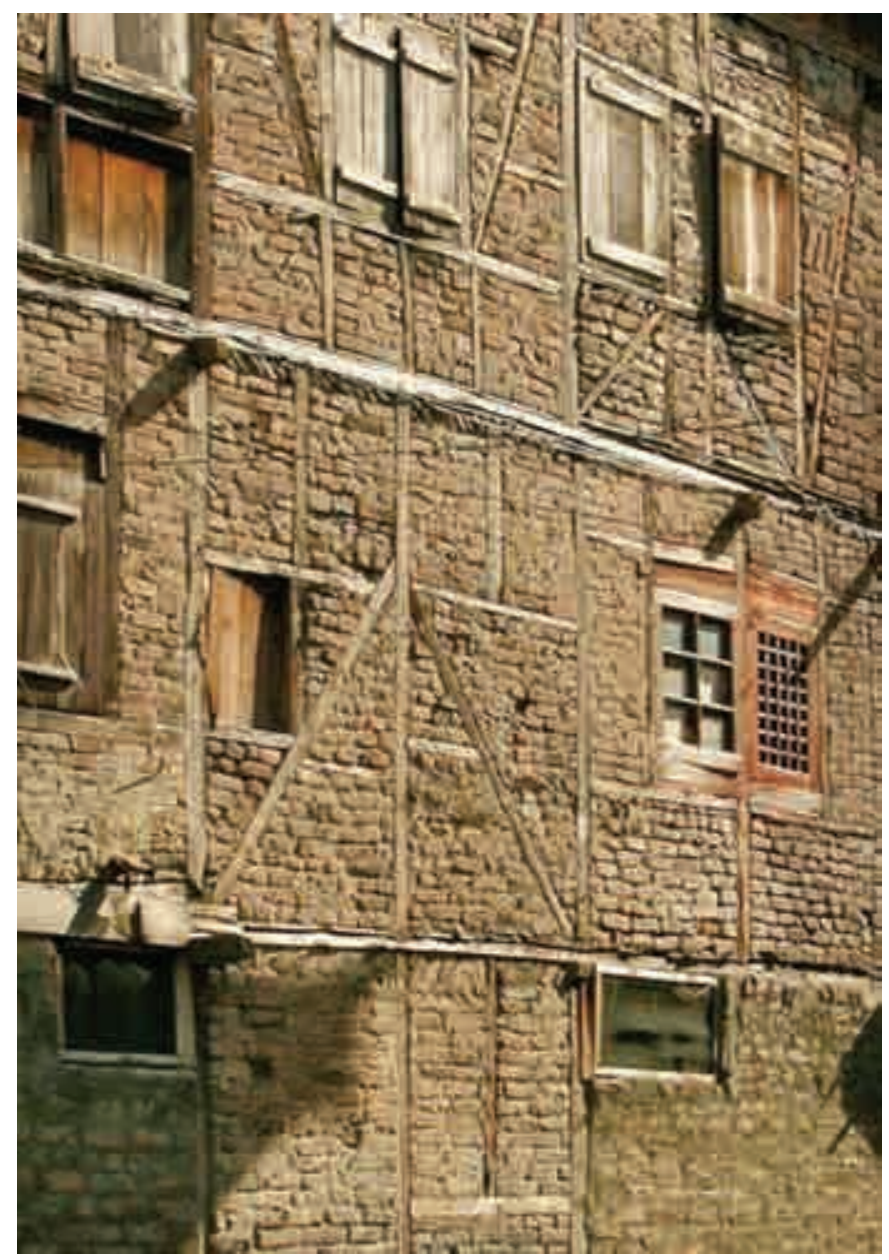

Figure 4. Dhaiji dewari, traditional construction in Kashmir

Source: Lagenbach, 2013

Another typical medio-oriental technique adopted in places with scarcity of wood is the TAQ technique that consists of insertion of large timbers that regularly supplies a row of bricks to confer elasticity to the wall structure in the out-of-plane direction (Figure 5). 
Figure 5. TAQ, traditional construction in Kashmir

Source: Lagenbach, 2013

Figure 6. Hımıș, traditional Turkish construction in Mudanya, Turkey

Source: Elena Perria, 2017

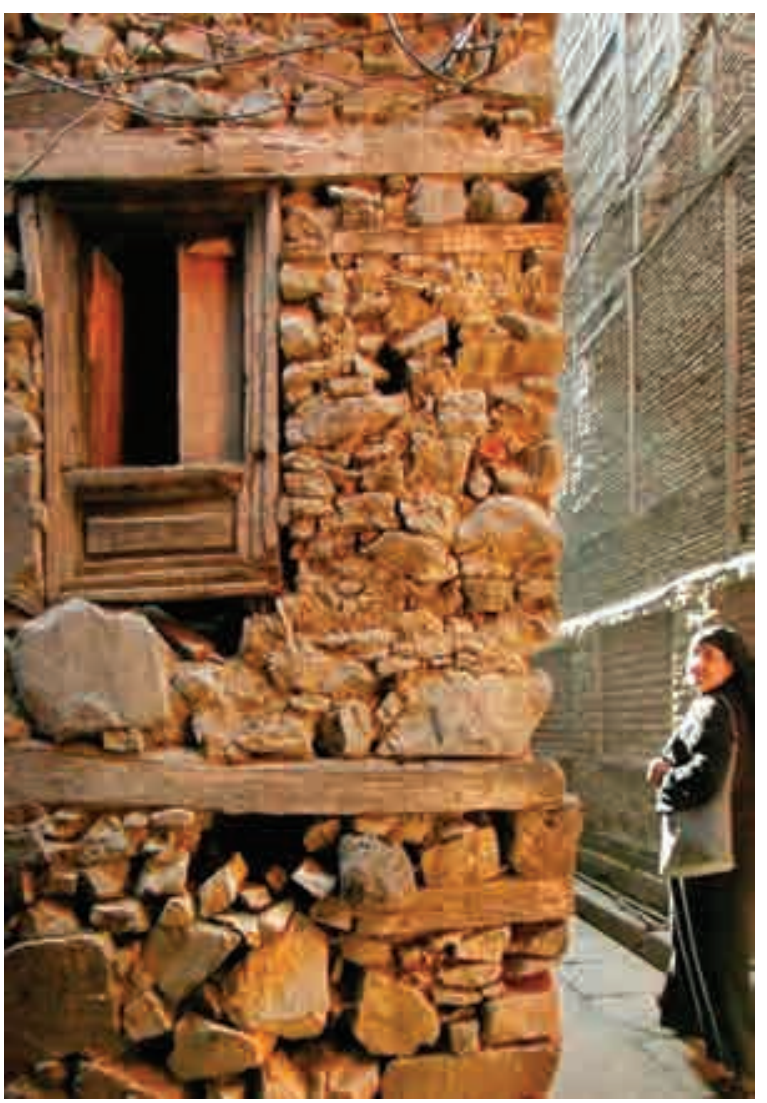

In Turkey, the most diffused techniques are the half-timber construction called Hımıs (Figure 6) and Bagdadi (Figure 7). The Hımış technique consists of a masonry wall, the foundations, on which the timber frame is located.

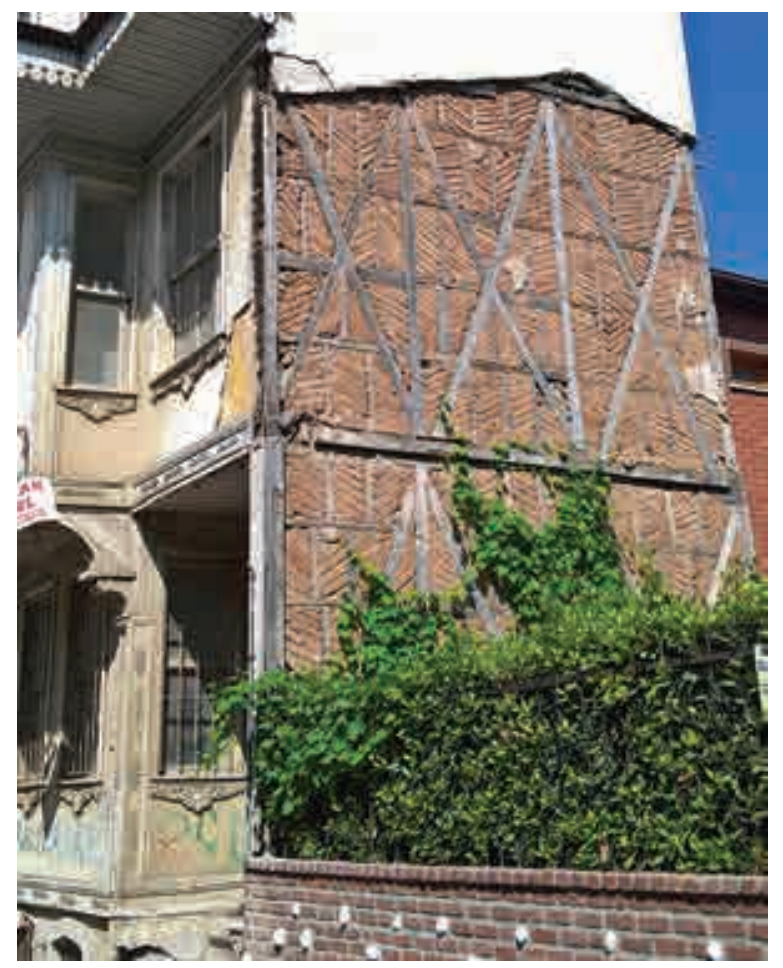




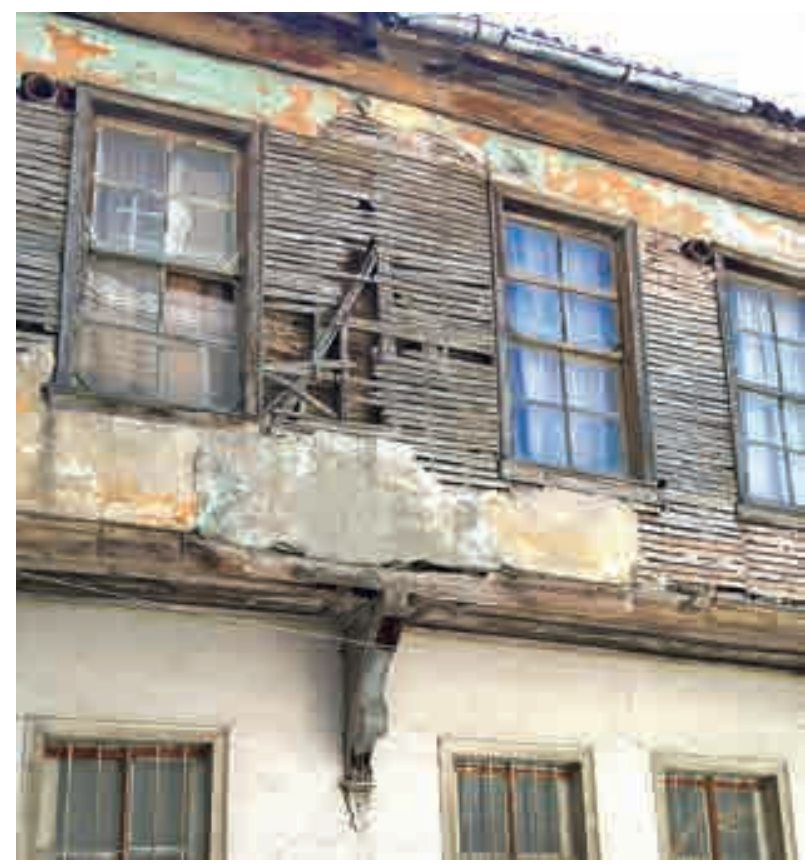

Typical is the infill of masonry in between the columns, beams and studs, filled either by brick or rubble stones. A variant on the hımış technique called hatil (Figure 8) covers the visible half-timber façade with horizontal wooden laces as finishing external layer.

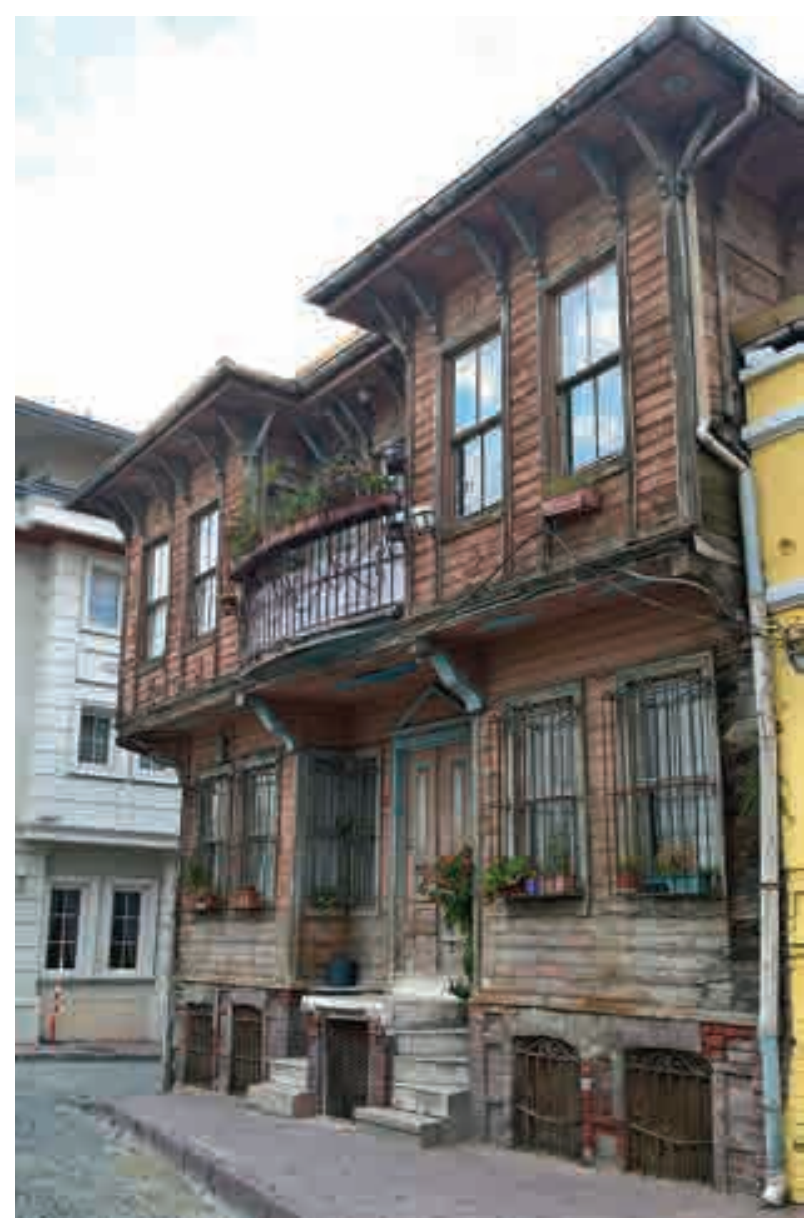

Figure 7. Bagdadi traditional Turkish construction in Mudanya, Turkey Source: Elena Perria, 2017.
Figure 8. Hatil, traditional Turkish construction in Istanbul, Turkey

Source: Elena Perria, 2017 
Because of the huge availability of wood on the territory within the Bosporus area around Istanbul, the technique called Bagdadi is developed. Here, the masonry infill is replaced by short rough pieces of wood plastered from the inner and outer side, in order to form a solid wooden wall. Because of the influence of the Ottoman Empire, the TAQ technique, used in combination with the other constructional techniques, is present also in the Turkish area (Figure 9).

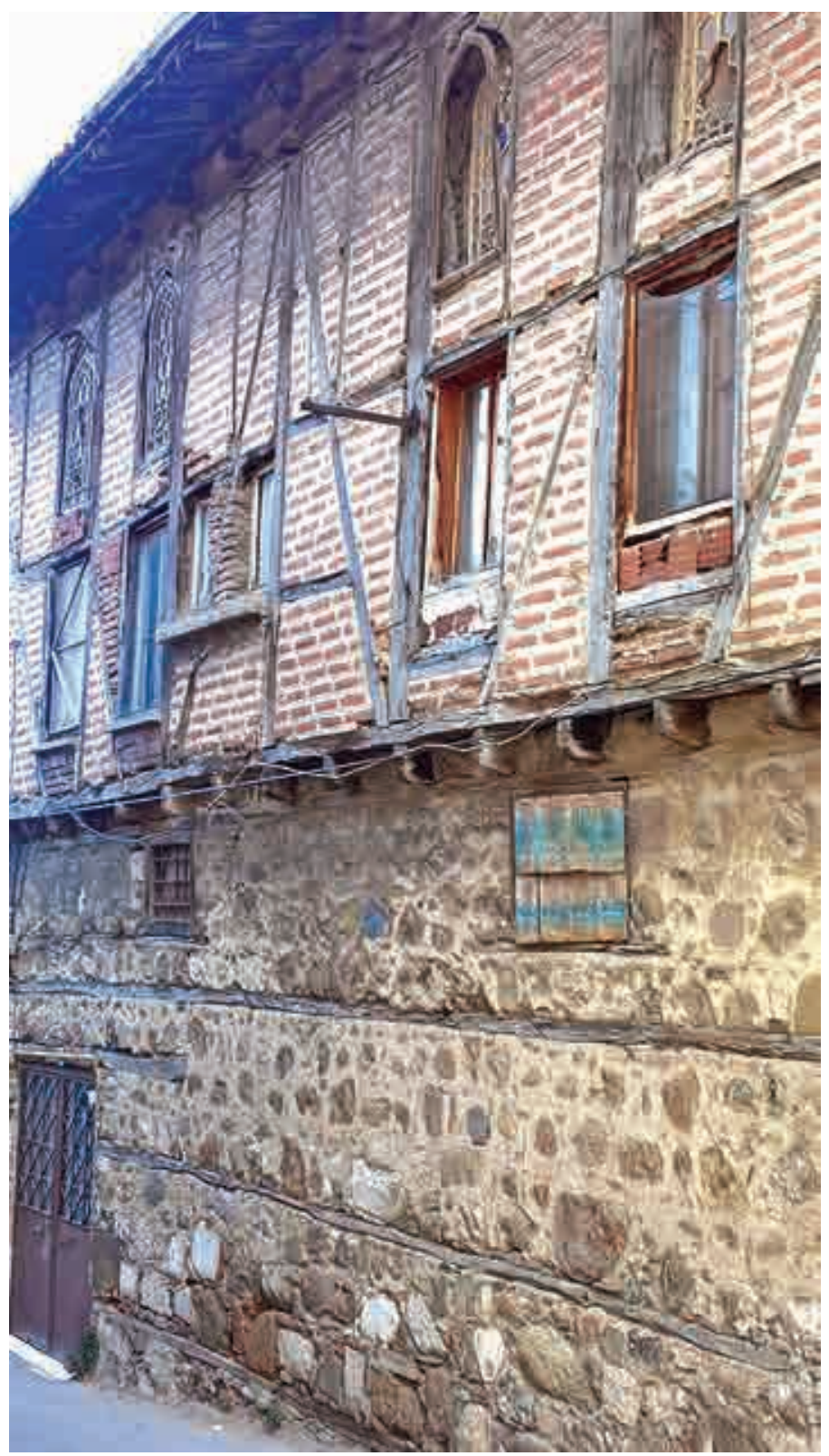

In Portugal, after the destruction of Lisbon due to the earthquake in the year 1755, the adoption of timber as a structural material became common. The system, called Gaiola Pombalina technique (from gaiola $=$ cage, in Portuguese) is a three-dimensional braced timber structure (Figures 10, II).

The system consists of horizontal, vertical and diagonal bracing members called St. Andrew's crosses. The timber structure is a self-bearing structure filled with either rubble or brick masonry, or even mud and hay (Poletti, 2013). 

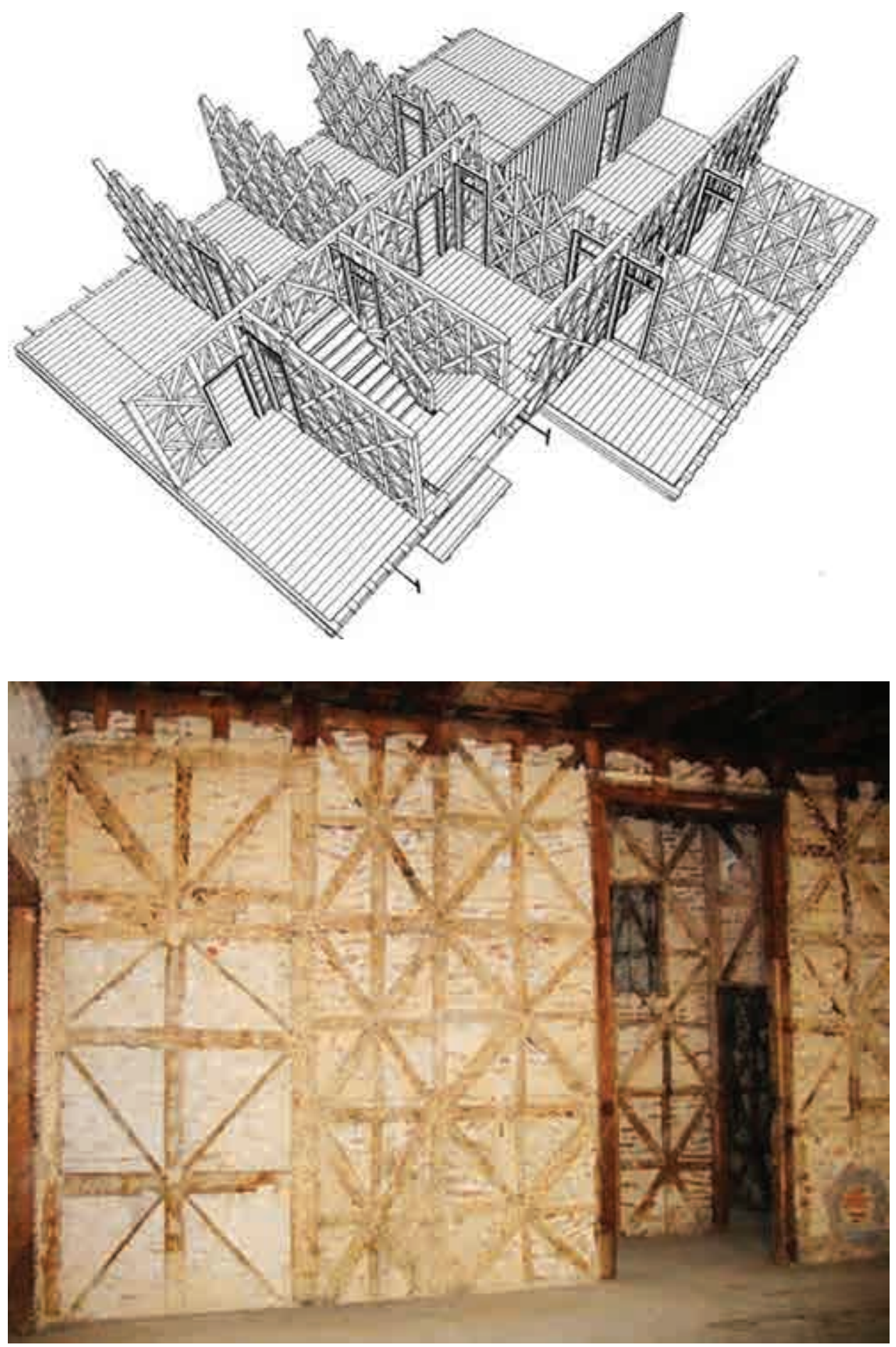

The "Casa Baraccata" (Figures I2, 13) is a structural system developed in the XIV century in the central Italy and diffused after the 1783 devastating earthquake occurred in Calabria, in the city of Messina (Vivenzio, 1783). This system is recognized as the first anti-seismic system who entered in the Bourbon state building regulations for the reconstruction of the destroyed cities. The technique is a two-dimensional frame inserted in masonry perimeter walls. The frame is placed in the inner part of the walls along both the façade and corners; the frame consists of horizontal and vertical elements reinforced with diagonal crosses to bear the lateral loads (Ruggieri, 2013).
Figure 10. Example of the disposition of the internal walls in the Pombalino system Source: Cóias in Poletti, 2013.

Figure I I. Gaiola Pombalina Source: Monumenta, Poletti, 2013 
Figure 12. Casa Baraccata (1783) Source: Vivenzio, 1783

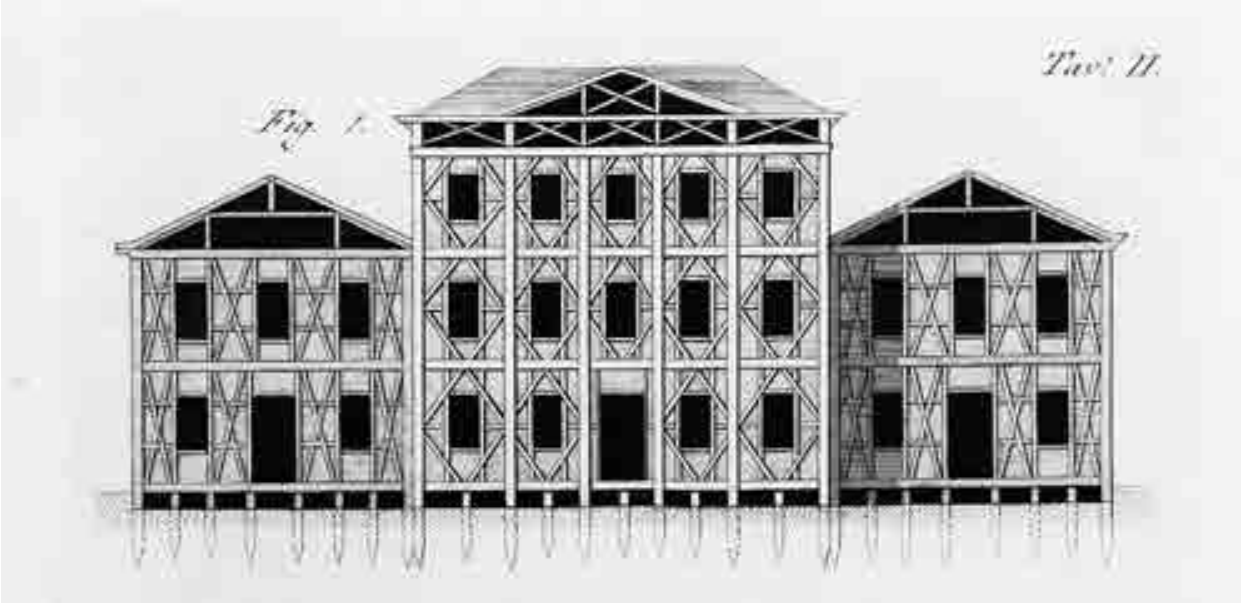

On the Greek island of Lefkas (also known as Lefkada) the buildings were built according to a special technique (Figure 14), present since the time of the Knossos Palace on Crete and Santorini islands (Touliatos, 2004). The main half-timbered structure is erected on a stone podium that includes the building's ground floor. The geometry of the timberframed walls consists of main vertical elements on horizontal connecting elements, and some sparse diagonals (Vintzileou et al., 2007; Makarios and Demosthenous, 2006). This structure rests on the masonry podium and is connected with the ground through timber columns that run beside the wall perimeter. Timber beams of the floor are connected to the walls through metal ties. Corner connections are usually strengthened with additional diagonal timber elements.

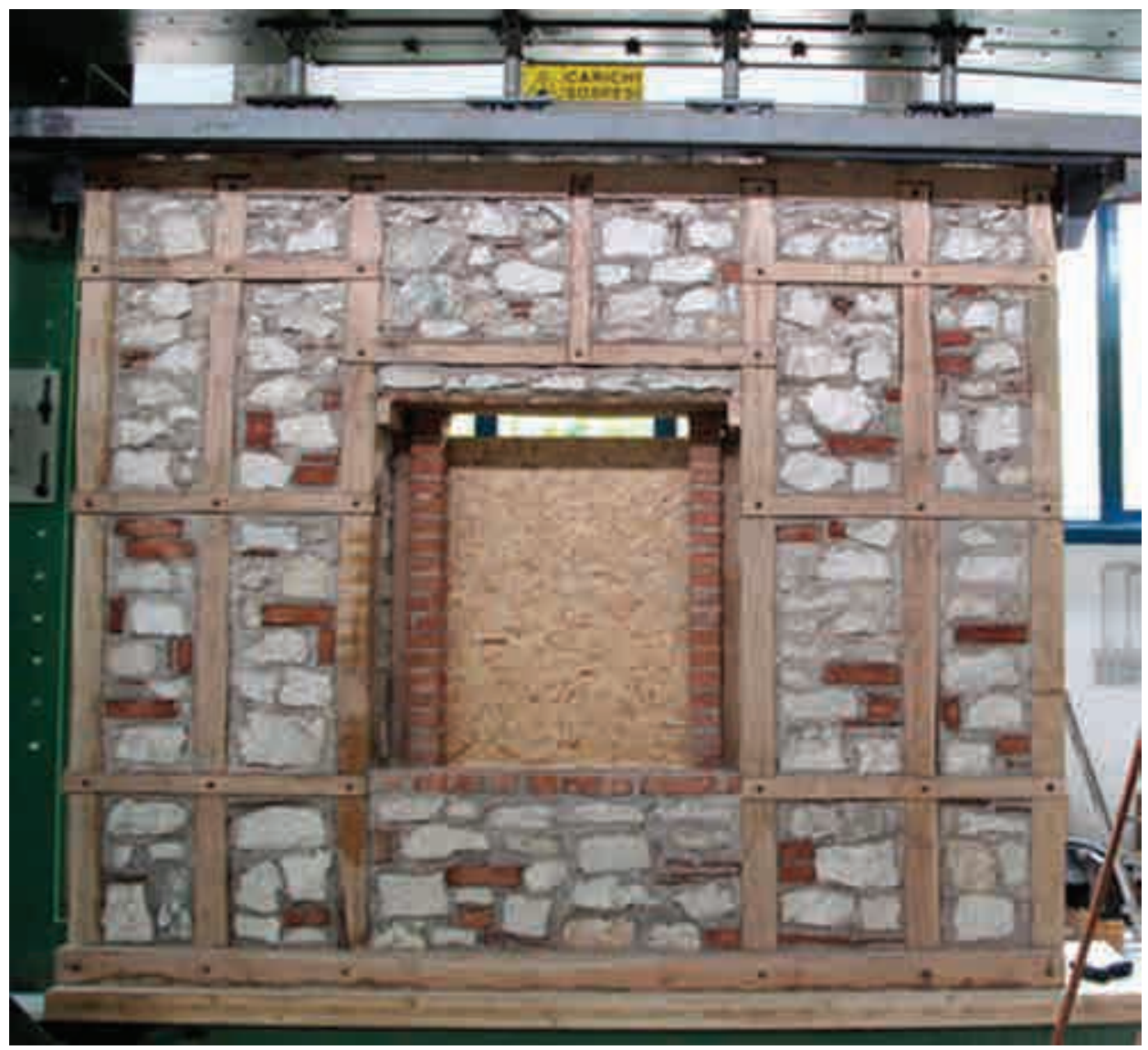

Figure 13. Casa Baraccata, reconstruction at CNR Trento

Source: Elena Perria, 2012. 


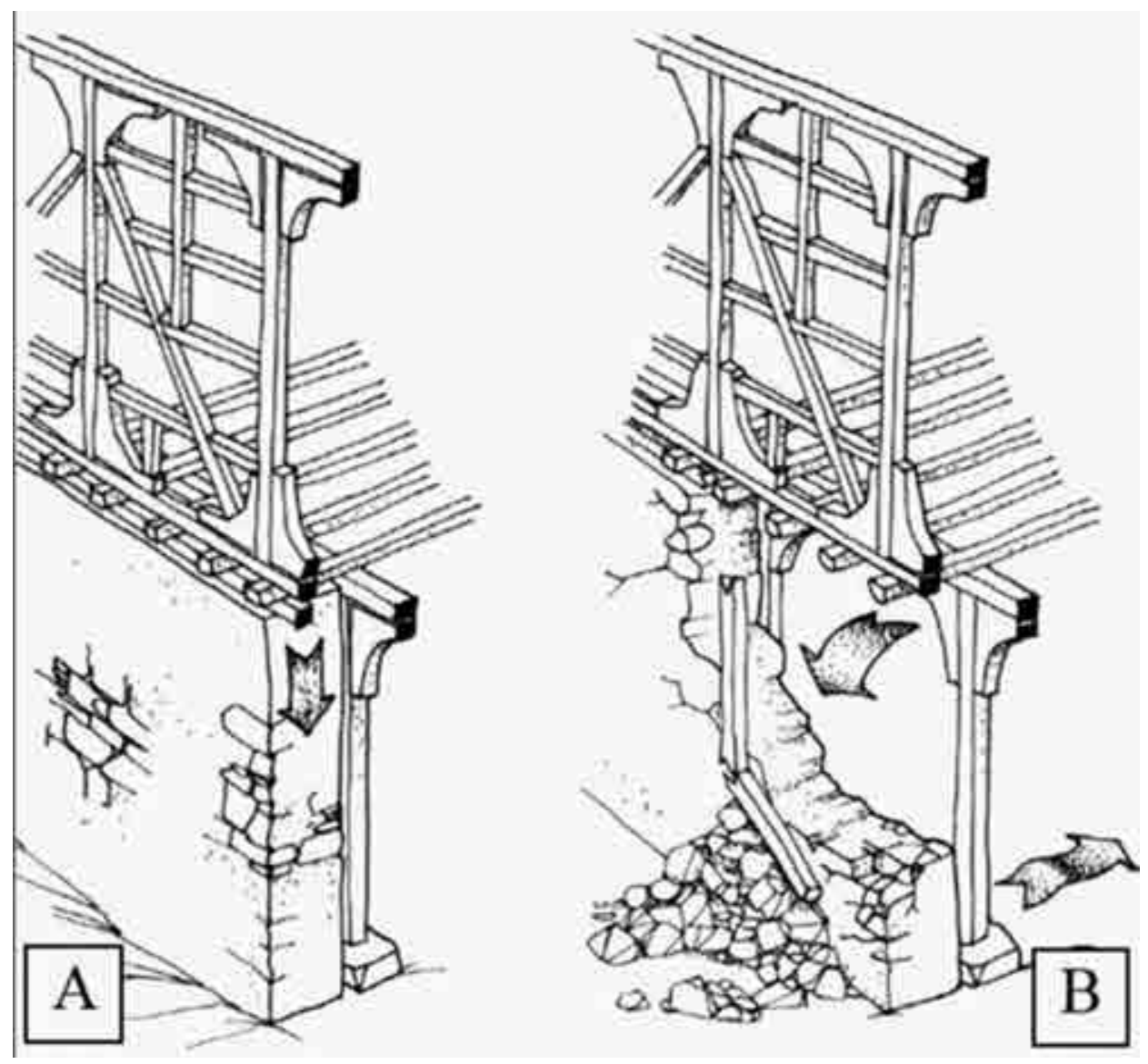

Figure 14. Lefka Technique Source: Touliatos, 2004.

\section{EUROPEAN CONTINENTAL EXAMPLES}

In Denmark, England, Germany and some areas of France and northern part of Spain, in localities where timber was in good supply, the timber constructions diffused with different names and regional changes. There is not one unique constructional technique that can describe the multiple regional techniques; nevertheless, the European Continental and English traditions have very similar general characters that evolved from the main typologies of half-timbered and timber-frame structures. In England, the most diffused were the aisled construction, the Cruck construction, the box frame and the most mature and effective post-and-truss structures. In Germany, the post-and-truss structure diffused with the name of Geschossbauweise; more, a further improvement in the German structural tradition consists of the Stockwerkbauweise also known as storey framing or Wealded frame in Kent and Sussex, England (Ashurst, 2012).

Following are described the main English and German half-timber structures. For all of them, the evolution described in the paragraph "Origin of modern timber structural systems" is completed: the use of posts joined on a sill beam on masonry or stone basements is established.

\section{Cruck construction}

"A true Cruck construction consists of a pair of curved timber (or rarely) straight, serving as the principals of a roof, and stretching to a point at or close to the apex of the roof from a level well down to the side walls" (Alcock, Barley, Dixon, Meeson, 1996). The Cruck frame (Figure I5) rose the most interest because of their simple architectural and sculptural quality. This 
Figure 15. Example of cruck frame structure Source: Ashurst, 2012 basic system of construction is very characteristic of the local west England tradition and remained in use for over 400 years. It was inspired with the naval engineering, because it used curved trees forming at the same time the main load-bearing structure and his bracing.

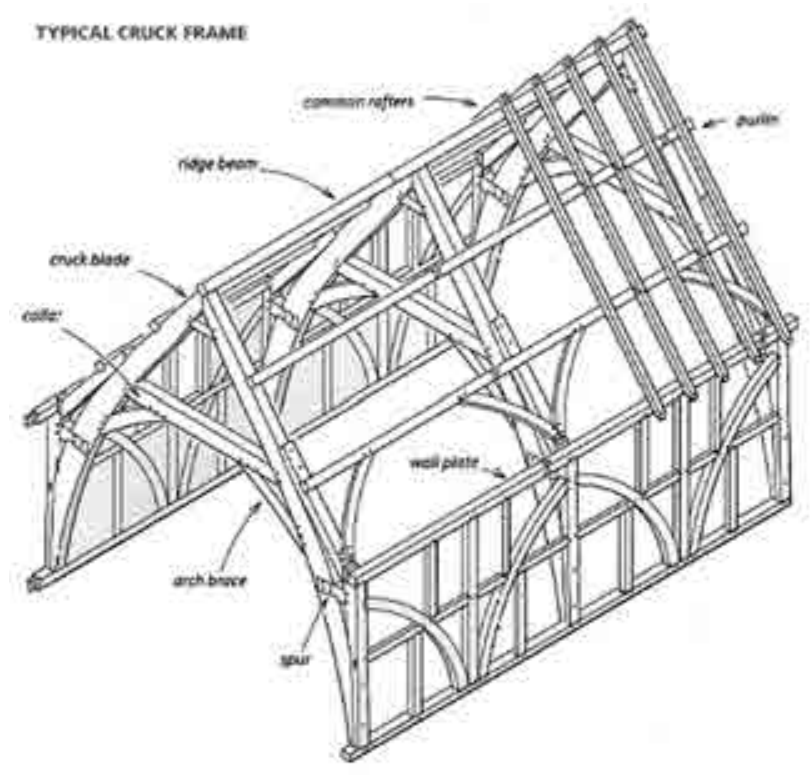

\section{Box frame}

The simplest version of the half-timber construction known in England, is the box frame (Figures 16, 17); this consists of an independent box structure, composed by two longitudinal wall frames joined together by tie-beams and covered by a rafter roof.

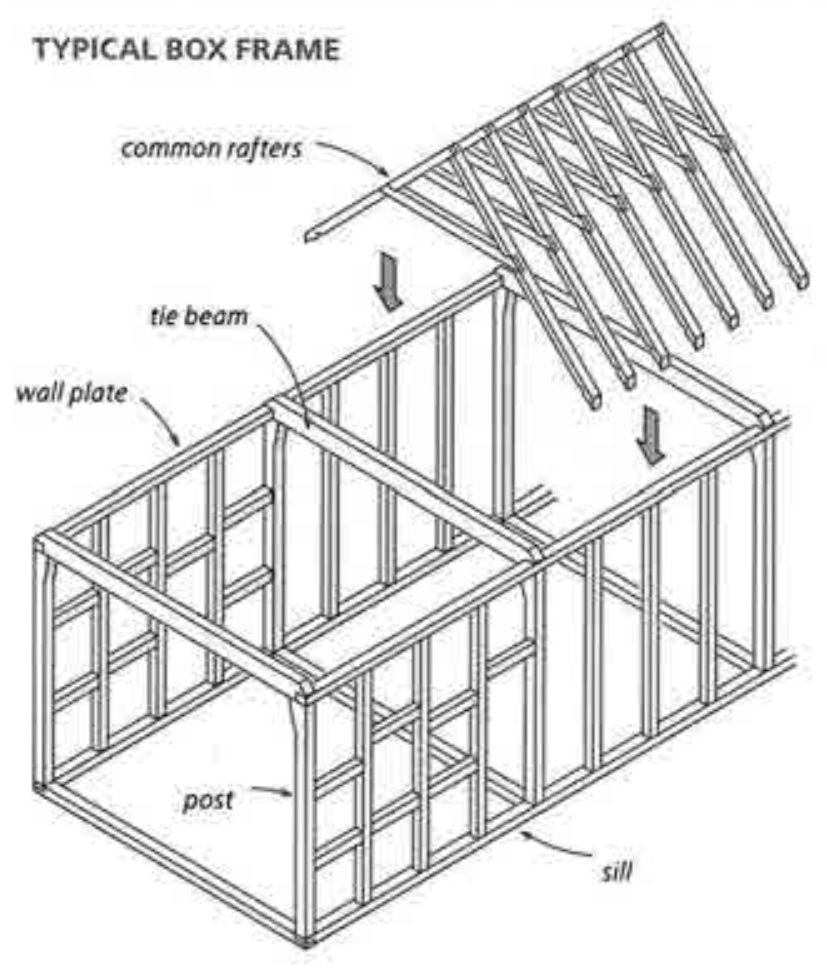

Figure 16. Example of box frame structure Source: Ashurst, 2012. 


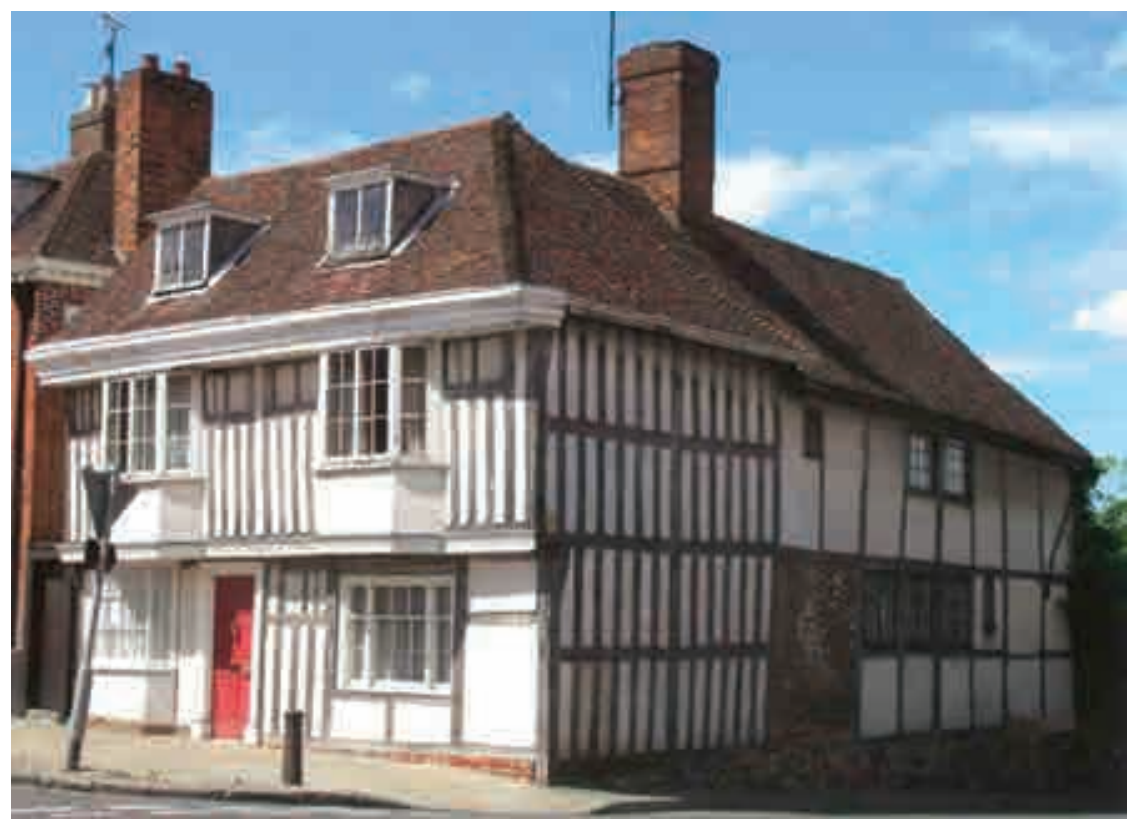

Wall frames are longitudinal load-bearing elements consisting of jointed vertical, horizontal elements, forming panels with infill of different materials. The wall frames are composed by main vertical elements called main posts and vertical supplementary elements called studs; these are connected in the lower part with a sill beam and in the upper extremity with an horizontal beam called wall frame. At the middle of the height, the studs or posts are connected together through horizontal pieces called nogging pieces. Both posts and studs are one-piece-posts extend from the sill beam to the underside of the wall plate. To brace the structure in the transversal direction, the opposing wall frames are connected by tie-beams at regular intervals. The tie-beams are notched to the wall plates to combine the two orthogonal frames in an integrated structure.

The whole structure is covered by the rafter roof joined on the wall plate with notched connection. Being the simple rafter roof directly connected with the underneath wall frames through the wall plates, it produces horizontal forces on the underneath walls, in the areas that are not provided with the tie-beams. Although tie-beams helps avoiding the weight of the roof spreading the walls outwards, collars were added to the pair of rafters to lessen the horizontal action of the roof on the underneath box structure.

\section{Post-and-truss structure}

Between the IIth and I5th century, the German Fachwerk technique developed the post-and-truss structure (Geschossbauweise). In this evolved form of construction (Figure 18), wall-frames, cross frames and roof (both rafter or purlin roof) are combined in an integrated structure.

As well as in the box frame, the vertical posts are continue timbers that elevate from the sill beam to the underside of the wall plate (Figure 19).

For this reason, the maximal height of the timber determinates the height of the structure. Because of the limited length of the available timbers, the maximum height of these buildings was two levels, approximatively $10 \mathrm{~m}$. The load-bearing structure consists of two of parallel wall frames (Figure 20).
Figure 17. 16th century box frame town house in east Kent, UK

Source: Ashurst, 2012 
Figure 18. Example of post and truss frame Fonte: Ashurst, 2012.

Figure 19. Ständerbau (Quedlinburg, Wordgasse 3)

Source: www.Fachwerk.de
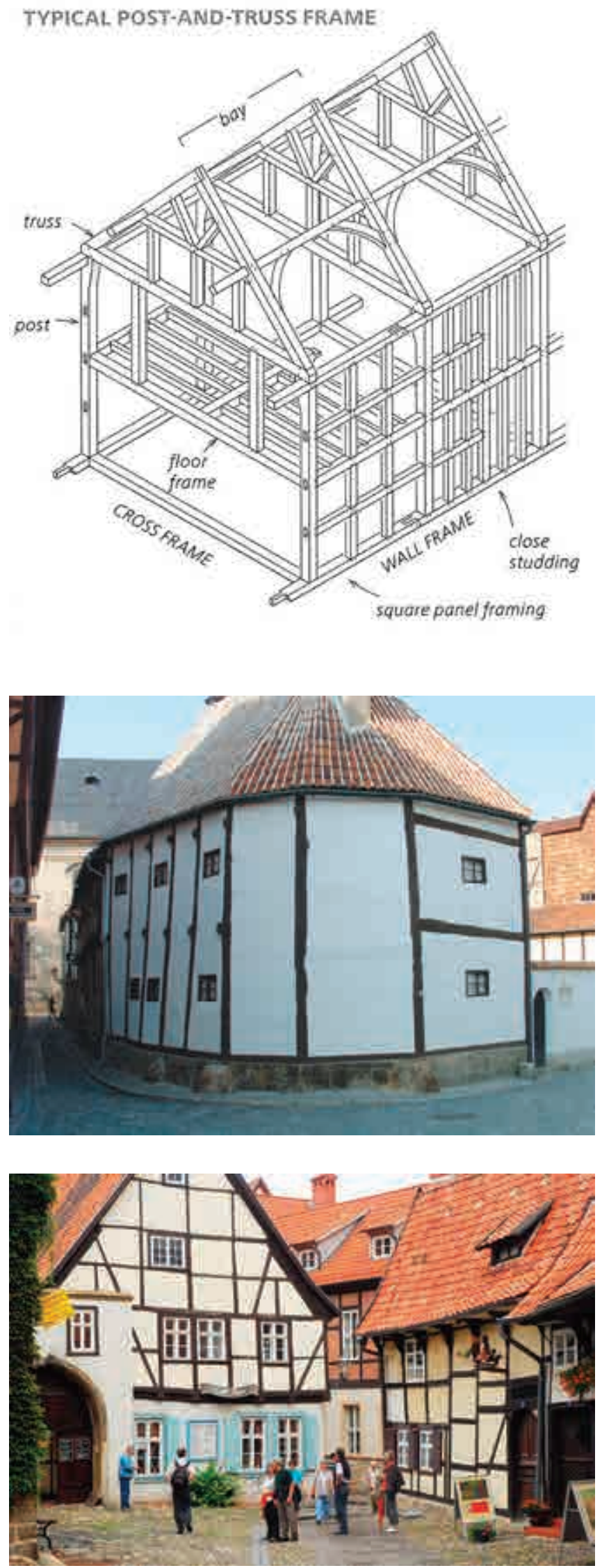
The wall frames are composed by posts, connected in the upper part with the wall plate and in the lower part to the sill beam, through mortise and tennon or halved joints. The wallframes, are stiffened with diagonal braces and horizontal noggin pieces. The diagonal bracing in correspondence of the right-angle connections between post and beam in the wall is installed to prevent the racking or movement of the structure. The used joinery technique was in earlier structures the halved dovetailed joint and in later ones mortise and tennon.

In the post-and-truss structure (Geschossbauweise) are usually present full and long braces (Vollstrebe / Langstrebe); they extend respectively along the whole height of the frame, from the sill-beam to the wall plate, and along the half of the frame's height, from the sill beam at ground or first floor (Figure 2I).

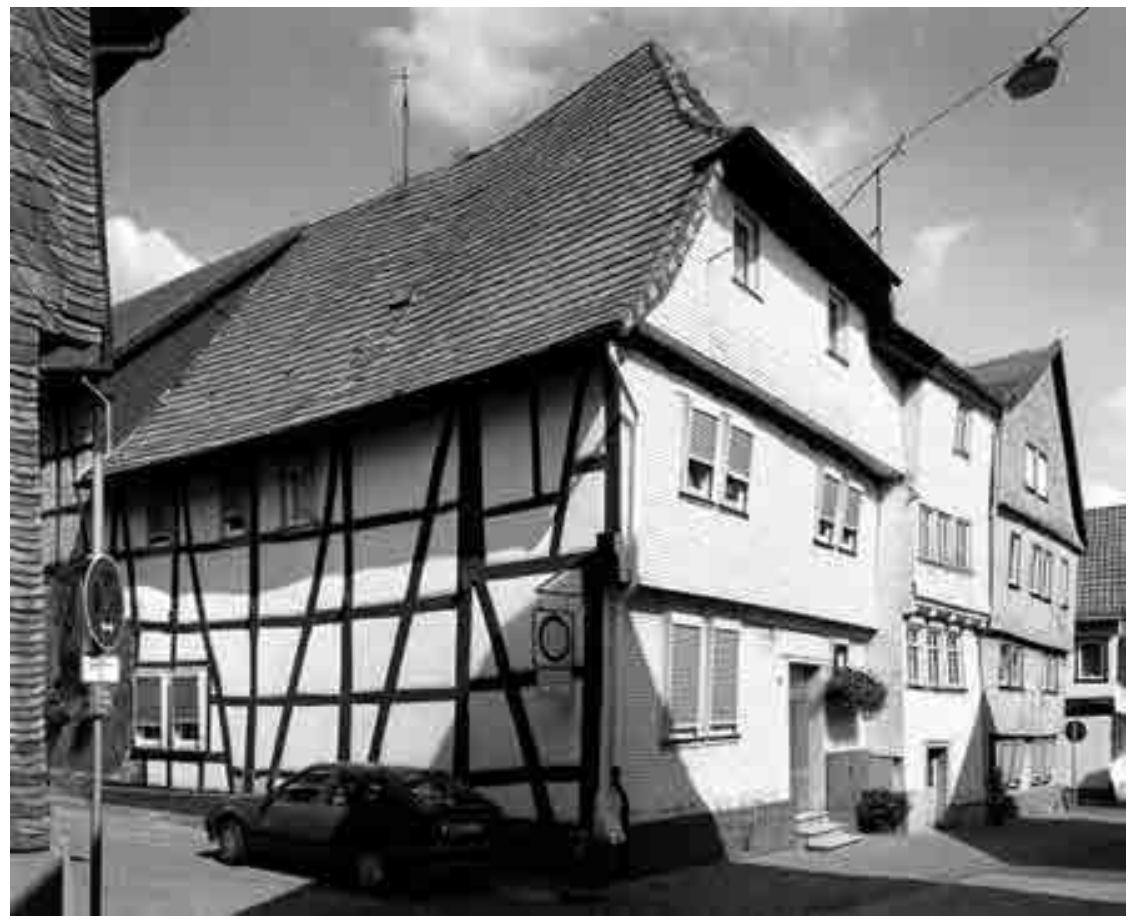

The bracing helps keeping the frame on plumb, level and square. The most common inclination is the one in which the upper far-end points outwards and they are disposed symmetrically on the two sides of the corner. The vertical supplementary elements that compose the wall frames are called studs and the horizontal ones nogging pieces. In the English tradition, the studs are at closer distance one with the next one, while In the German tradition the space between the studs is wider and that framing form acquires the name of square panel framing or diamond paneling (Figure 17).

In order to improve the load-carrying behavior and avoid stability problems as in the box frame, the supporting framework is here provided with cross frames. The opposing wall frames are connected by transversal cross frames at regular intervals, stiffened with horizontal rails and diagonal braces with different heights at regular intervals. The first joining technique employed in the cross frame is the extended mortise and tennon, that later on was replaced by the hidden mortise and tennon. The evolution in the connection system have a durability reason; in fact, the extended mortise and tennon was mainly exposed on the external part of the building, causing a quick decay in the point of stagnation or direct exposition to the rain (Figure 22).
Figure 21. Long braces in Untere Fulder Gasse 28, Alsfeld

Source: Landesamt für Denkmalpflege Hessen. 


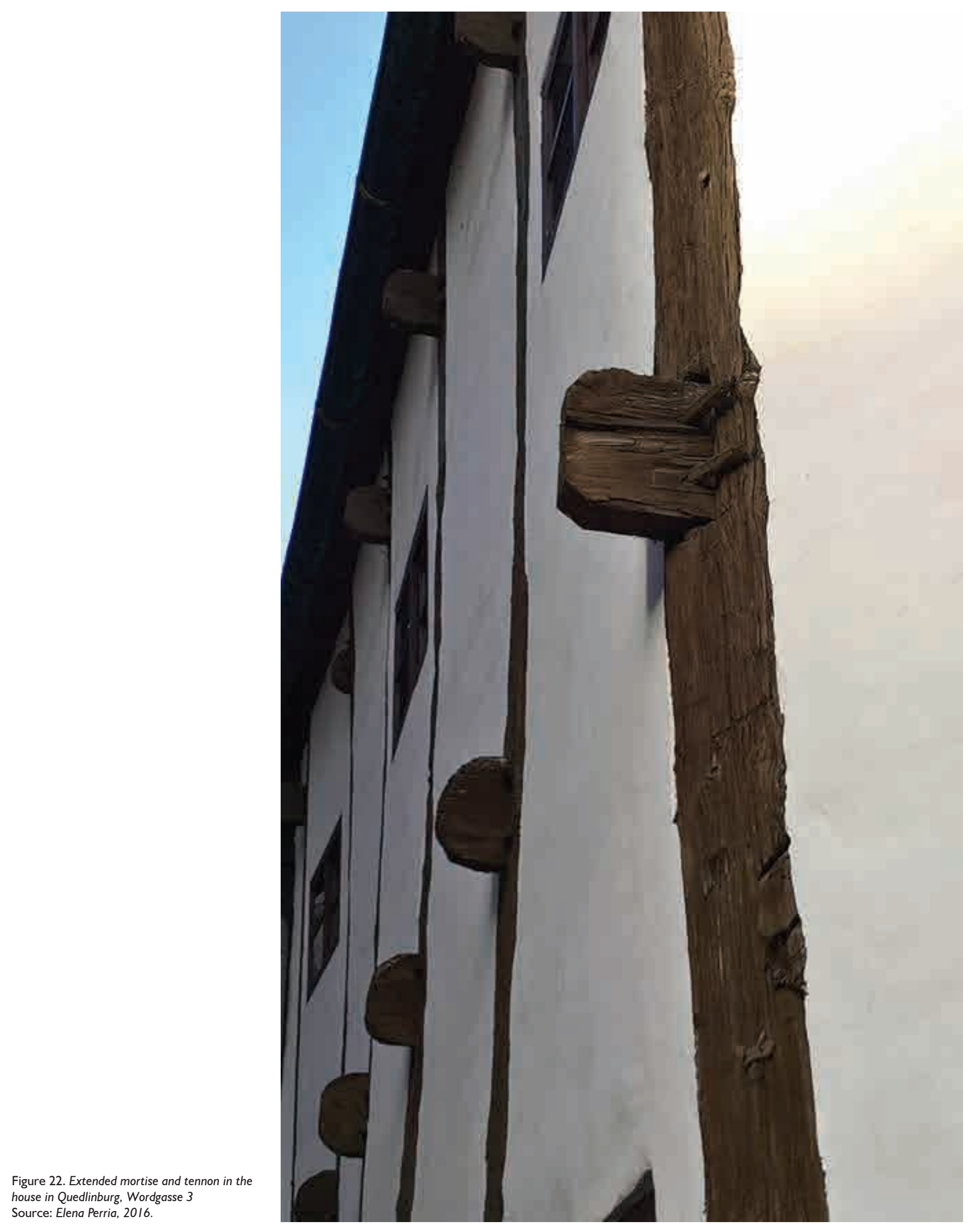


Even the post and truss frame (Geschossbauweise) was an evolved structure it still presented some structural problems:

- The height of the construction is limited to the length of the posts.

- The braces are the only stability system to resist lateral and on-plane loads; because of their length, the long braces are in fact susceptible to out-of-plane buckling or tilting.

- The superposition of the floors over the length of the posts was not possible, and the maximum height was usually limited to two floors.

\section{Story framing or Stockwerkbauweise}

From the 14th century, because of the increasing population in the cities, the new technique called story framing was developed for the construction of multi-story buildings in urban areas. The story-framing construction (Figure 23) presents similar characteristics to the post-and-truss construction, but it is improved in the point of weakness typical of the post and truss frame.

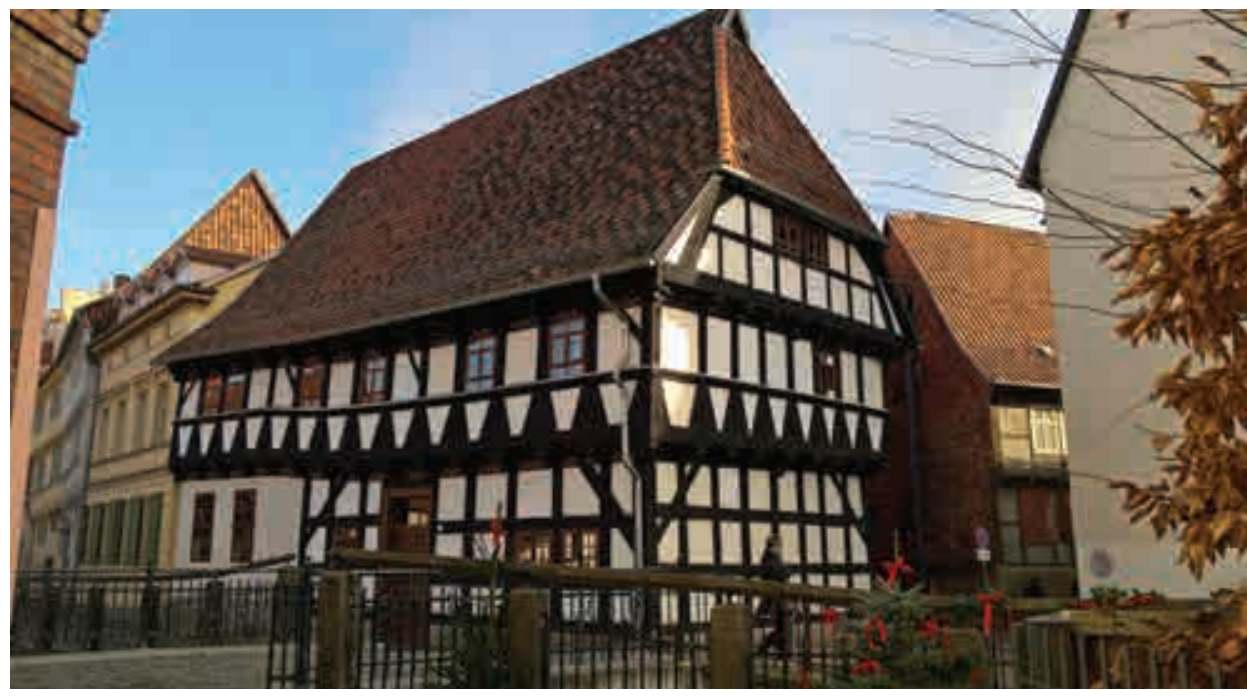

It consists in a half-timber structure characterized by multiple stories with a characteristic second-story (or more stories) overhang on the façade's side. A rafter roof but also a purlin roof mainly cover the structure. The system has the peculiarity of having been built with shorter timbers respect to the one needed in the post-and-truss construction, in spite of the possibility to build in height. Structurally speaking each of the stories is conceived as a cage independent from the lower or the upper one: the frame of sleepers, posts, braces and wall-plate system elevates for only one level. Multiple levels can be superposed thanks to the cantilever system.

Each further floor is conceived as a closed structural box composed by posts connected in the lower part with a sill beam, in the upper part with a headplate, and braced each other by means of braces. The main connections used were the lapped joint and the mortise and tennon joint. The box is covered with ceiling joists laying on the head plate, and connected to it with notched connection. In very narrow small ground areas, the ceiling joists of each floor were installed perpendicular to the long axis of the house. The upper laying storey is intented to be supported on the horizontal cantilever beams, the jetty bressummer, that lays on the ceiling joists of the lower level and distributes on them the weight of the overlaying story. The main advantage of the cantilever is structural: the cantilever at the end of the beams partially counterbalance the load carried by their spanning portions. On the corners the structure is reinforced by mean of tension braces (Figure 24).
Figure 23. House in Storey framing or Stockwerkbauweise in Quedlinburg Source: Elena Perria, 2016. 
Figure 24. Sketch of the corner particular of Haus Amthof in Alsfeld of the middle 15th century

Source: Author's files.
In this evolved technique, the bracing system is mainly by short-braces (Kurzstrebe) that include foot-braces (Fussstrebe), head-braces (Kopfstrebe) and St. Andrew's crosses. The short-braces (Figure 25) connect the half of the storey-height on the nogging pieces or the whole storey height. The head-braces run from the post / stud middle height to the upper wall plate. The foot-braces are either straight or curved braces that extend between the wall-plate or sill-beam and the middle height of a post / stud. Under this category are also included all the braces that extend for three quarters of the floor-height, also called "Man legs" (Beine eines Mannes). The special figure of the St. Andrew's cross is a cross form that connects the noggin piece to the upper or lower plates.
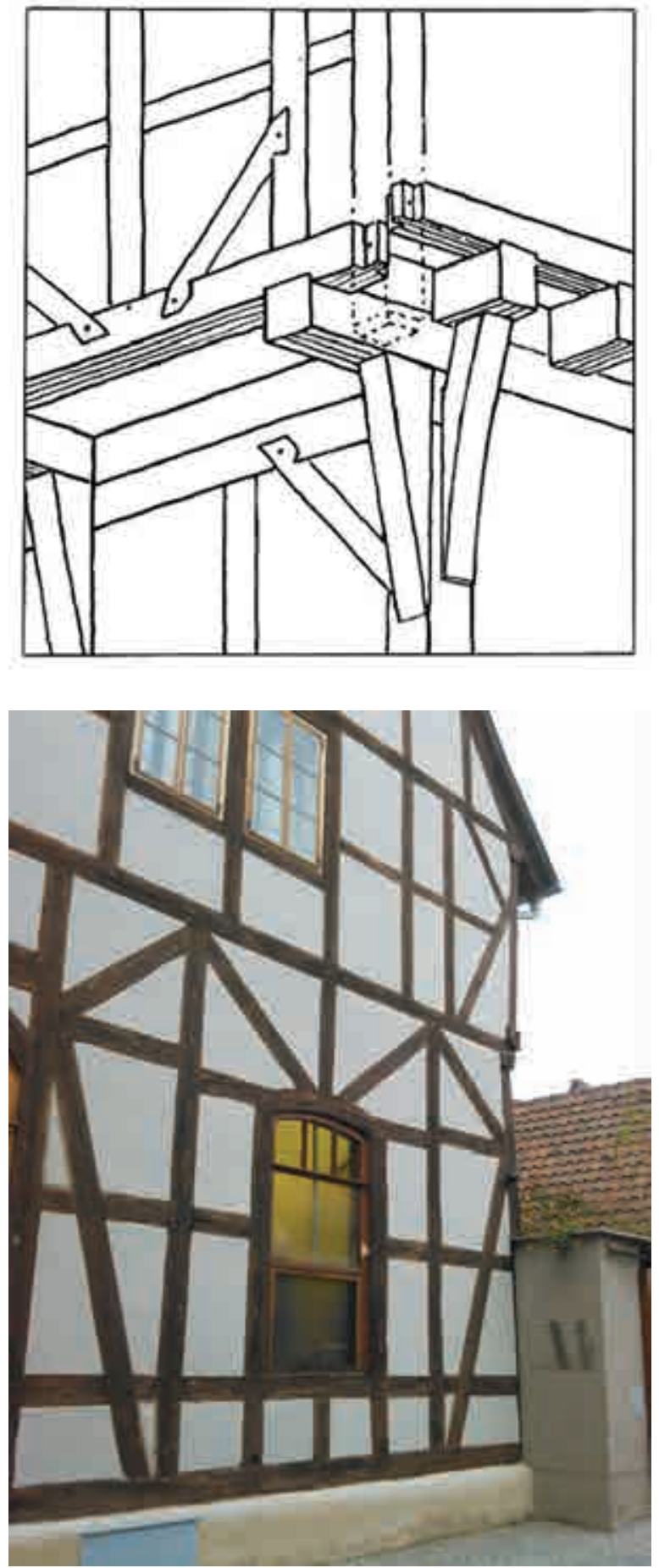


\section{COMMON FEATURES IN THE EUROPEAN CONTINENTAL CONSTRUCTIONAL SYSTEMS}

The European continental constructional systems contain common features in terms of foundations, roofing and finishing systems. As well as the constructional techniques themselves, also such sub-systems evolved and improved from the middle age, period of diffusion of the half-timber techniques, to the most modern techniques in the XIX century. It follows a short introduction on foundations, roofing and finishing systems, as well as of carpentry connections.

\section{Foundations}

The massive substructure for the foundation wall of half-timbered buildings is of erratic blocks, rubble stone covered in lime mortar or trass mortar, and also built in brickwork in areas with lack of stones. The cellars has often arched or vaulted roof in sandstone masonry, or covered with wooden beams to the first level. In the high water areas, close to rivers, the ground floors were often built massively.

\section{Roofing systems}

The main typologies of triangulated roofs structures used on the half-timber and frame structures are both rafter roof and purlin roof. The simplest form of a rafter roof (Figure 26) consists of common rafters which extend from the wall plate to ridge.

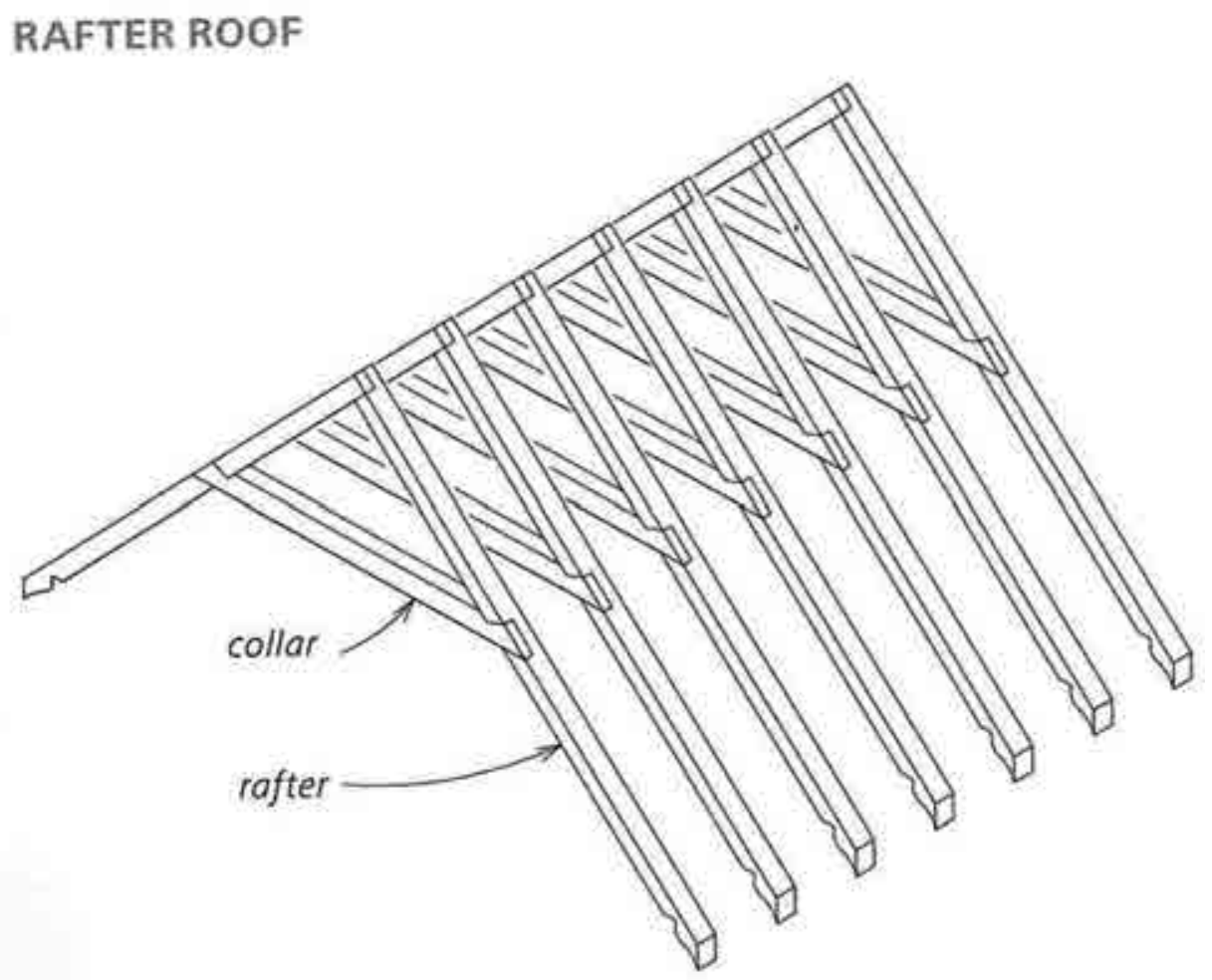

This roofs type is characterized by small spans up to 8 meters. The rafters are loaded with combined compressive and bending action. The reaction forces on the rafters cause an horizontal component in the bottom-end of the rafters that produces punctual horizontal forces on the vertical walls at the base of the roof. For this reason, a first improvement is the insertion of a wallplate connected with the main rafters in their bottom extremity

Figure 26. Example of simple rafter roof Source: Ashurst, 2012 
Figure 27. Example of rafter roof Source: Author's files.
Figure 28. Example of rafter roof with rafter bracing, collar tie, and combination of both Source: Holzer, 2015. with various connection geometries. The role of this structural element is to collect the horizontal forces on the rafters and to distribute them on the underneath wall in form of distributed load. To reduce the bending on the rafters this roof is also provided with a collar at I/3 of the height from the rafter's top. To avoid those horizontal forces at the base of the roof a triangular rafter roof form was also developed (Figure 27).

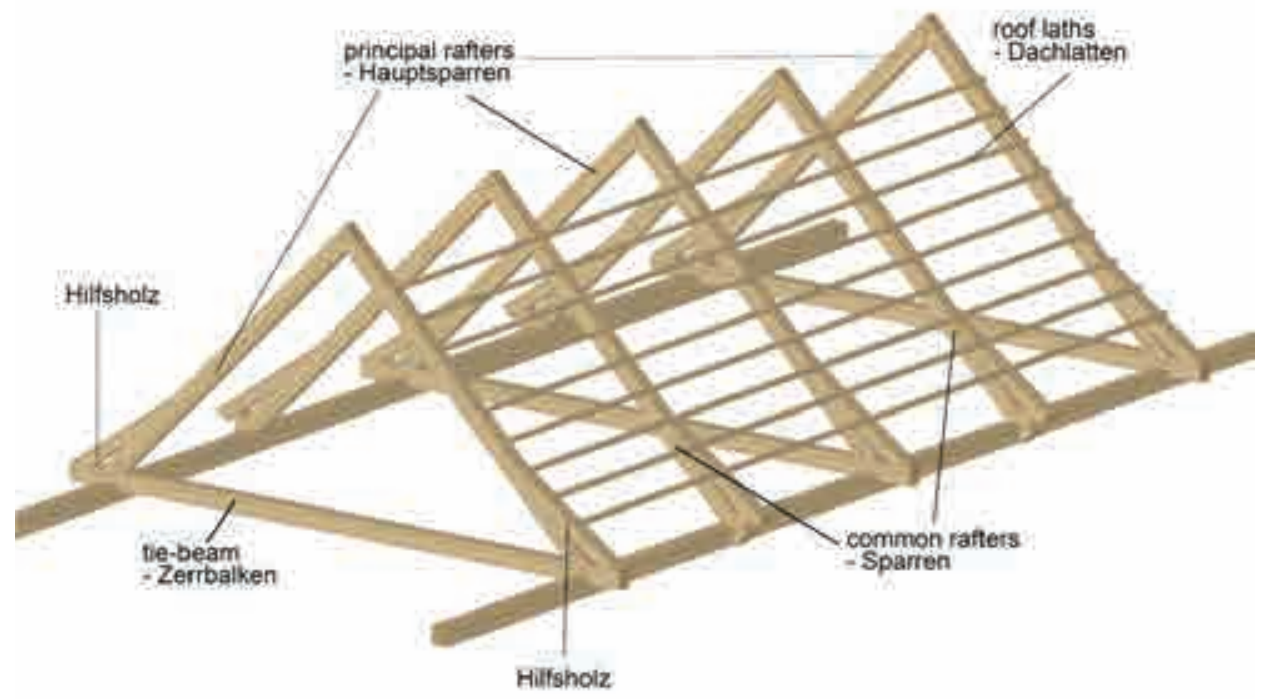

The rafter roof with triangular form the rafters are connected with a tie - beam in the bottom part of the rafters. This triangular structure is isostatic; therefore, is not transmitting horizontal forces on the underneath walls. This system is also combined with the presence of the wallplate.

With the increasing of the span of the space to cover up to $10 \mathrm{~m}$, in order to prevent the excess of bending in the rafters, the free span of the rafters is reduced through braces, collar ties, or cross braces (Figure 28). The advantages in using these constructional elements are the reduction of the free length of the rafters.
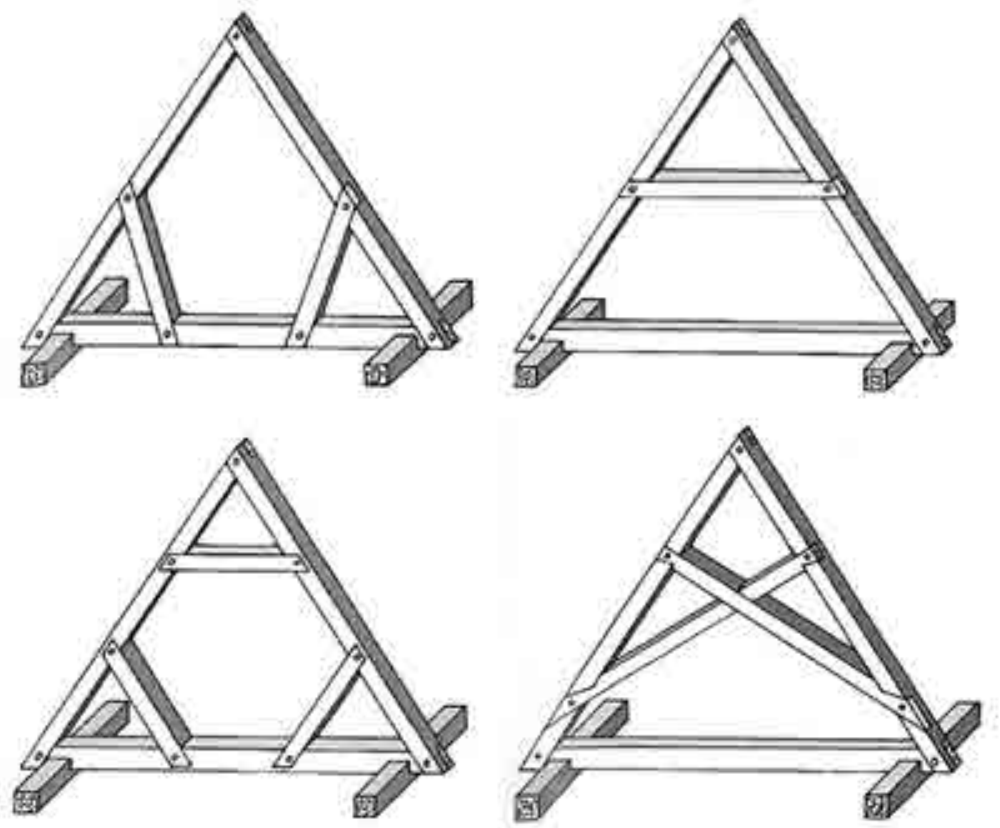
On the other side, the disadvantages of the rafter bracing, connecting the rafter with the tie beam, are that they constitute an additional punctual load for the tie beam; therefore, the tie beam is more bent. The cross bracing consists of two structural elements connected to the upper and lower part of the rafters. These cross in the middle with a lapped connection that reduces the cross section of the elements in their middle part to the half of the cross section. The advantages of the use of these elements is the symmetry and the transmission of the forces to the rafters instead of loading the tie beam.

More structural solutions characterized by progressive complexity with presence of double post construction (stehender Stuhl) and inclined post construction (liegender Stuhl) used to cover spans up to 12 meters are described in the Figure 29.

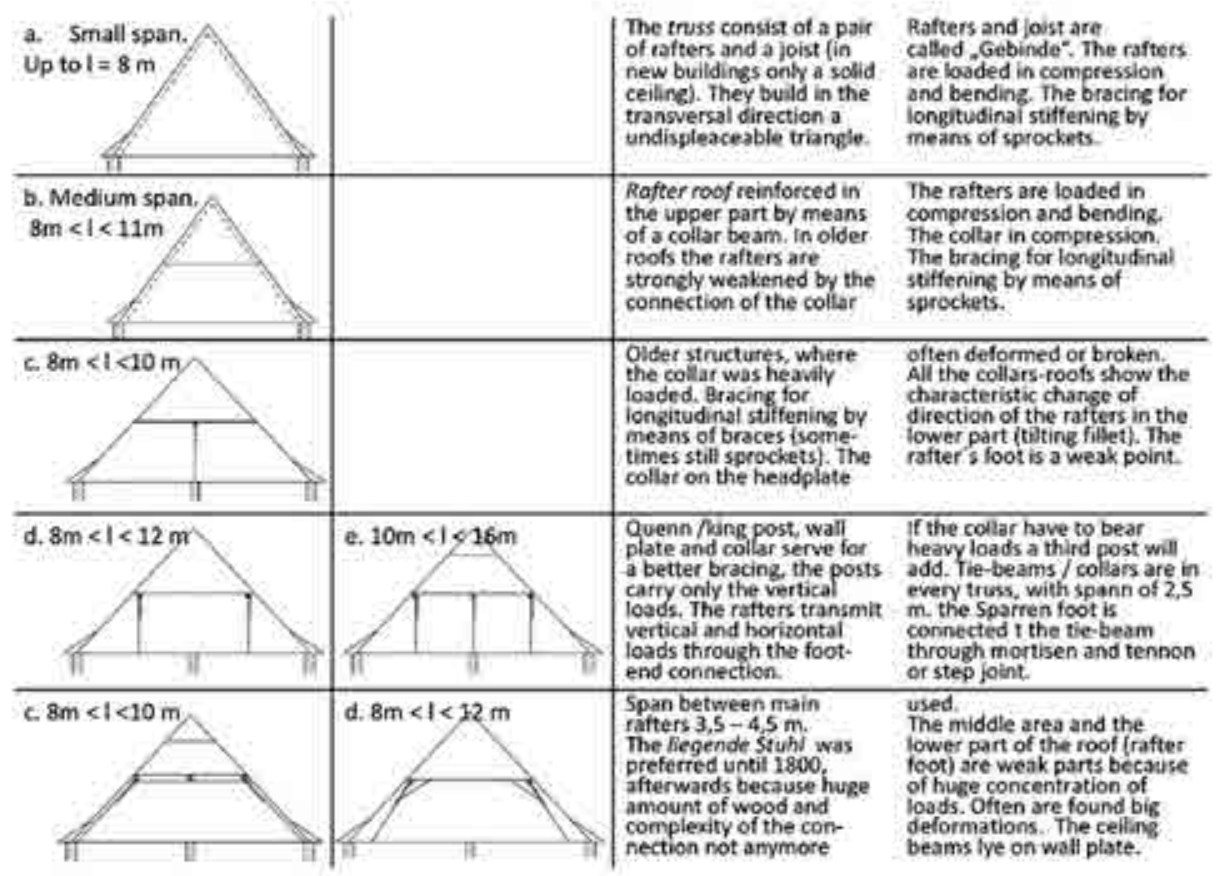

The purlin roof is characteristic of southern Europe or in general mainly adopted in areas where the supply of wood was not very abundant. The elements that compose a purlin roof are trusses or cross-frames, purlins and rafters. In a basic purlin roof the rafters are supported on horizontal timbers, the purlins, which transmit the roof load to underlying trusses or cross-frames. To resist the tendency of the roof structure to tilt out of plane, wind braces were usually (but not always) incorporated between the purlins or between the trusses. The structure is thereby divided into bays (Figure 30 ).

The trusses, according with the span they have to cover, acquire different configurations. For spans under 6 meters was employed the simple truss (Figure $3 \mathrm{I}$ ). The structural components are two main rafters loaded in combined compression and bending forces, connected to a tensile-stressed tie beam to form a triangular structure to which a king post is added as a tying supplementary element.

The next step is the introduction of two compressed struts in connection between the rafters and the king post to cover spans from $6,5 \mathrm{~m}$ to $13,00 \mathrm{~m}$. This structure is called king post truss (Figure 32 ).
Figure 29. Structural solution of rafter roof to cover different spans Source: Author's files. 
Figure 30. Example of purlin roof Source: Author's files.

Figure 31. Example of simple truss Source: Author's files.

Figure 32. Example of king post truss Source: Author's files.
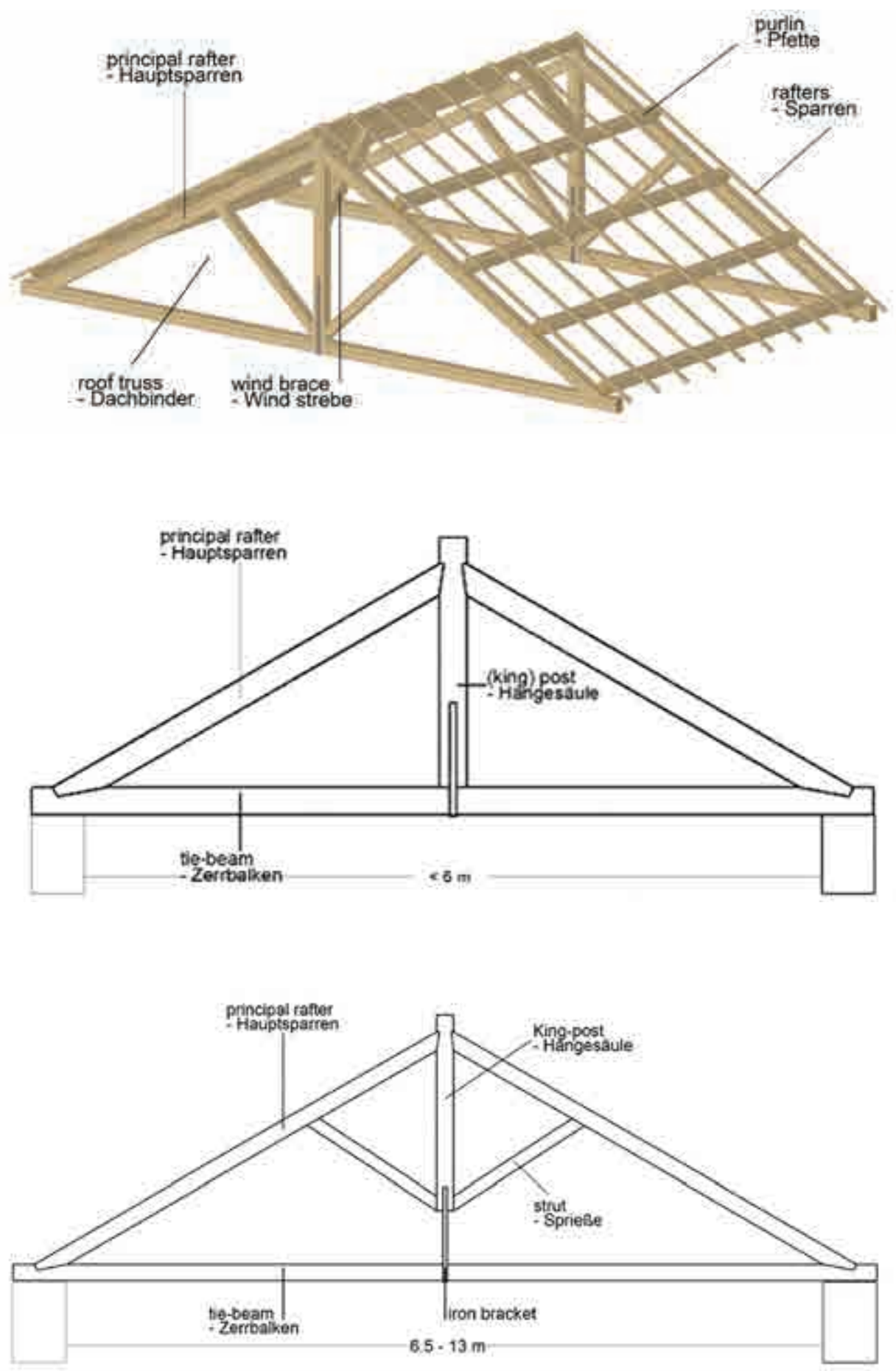

A further structure called queen post truss (Figure 33) was used to cover span length between $8 \mathrm{~m}$ and $12 \mathrm{~m}$. Two vertical posts, the queen posts, are symmetrically disposed at the two sides of the tie beam. Iron brackets were used to keep the queen posts, loaded in tension, in exact position on the tie beam, and to transmit the forces among the structural elements. The queen posts upper extremity was joined to the main rafters with the step joint. Further system to cover bigger spans have been developed until reaching the contemporary truss that works under the same static working principles as the roofs in the purlin roof. 


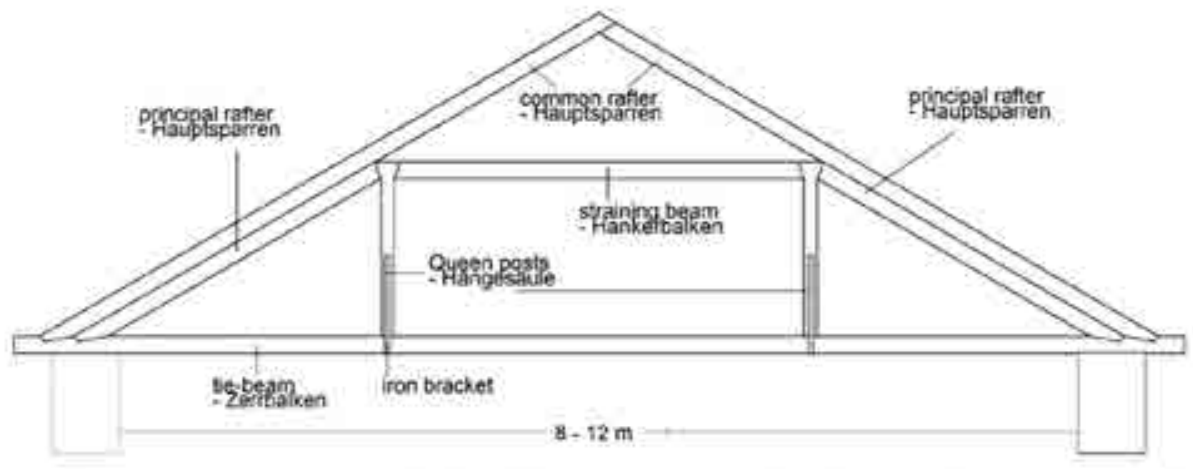

Carpentry connections

Carpentry connections are structural elements contained both in the main frame as well as in the roofing systems. Carpentry joints are able to transmit any kind of stress (compression, tension, shear or torsion) basing on the load transmission mechanism of contact compression and friction on notches and contact surfaces. The most diffused types of joint forms used in traditional half-timbered and frame structures carpentry are the half lap or half wood, mortise and tennon, step joints, and scarf joints (Figure 34).

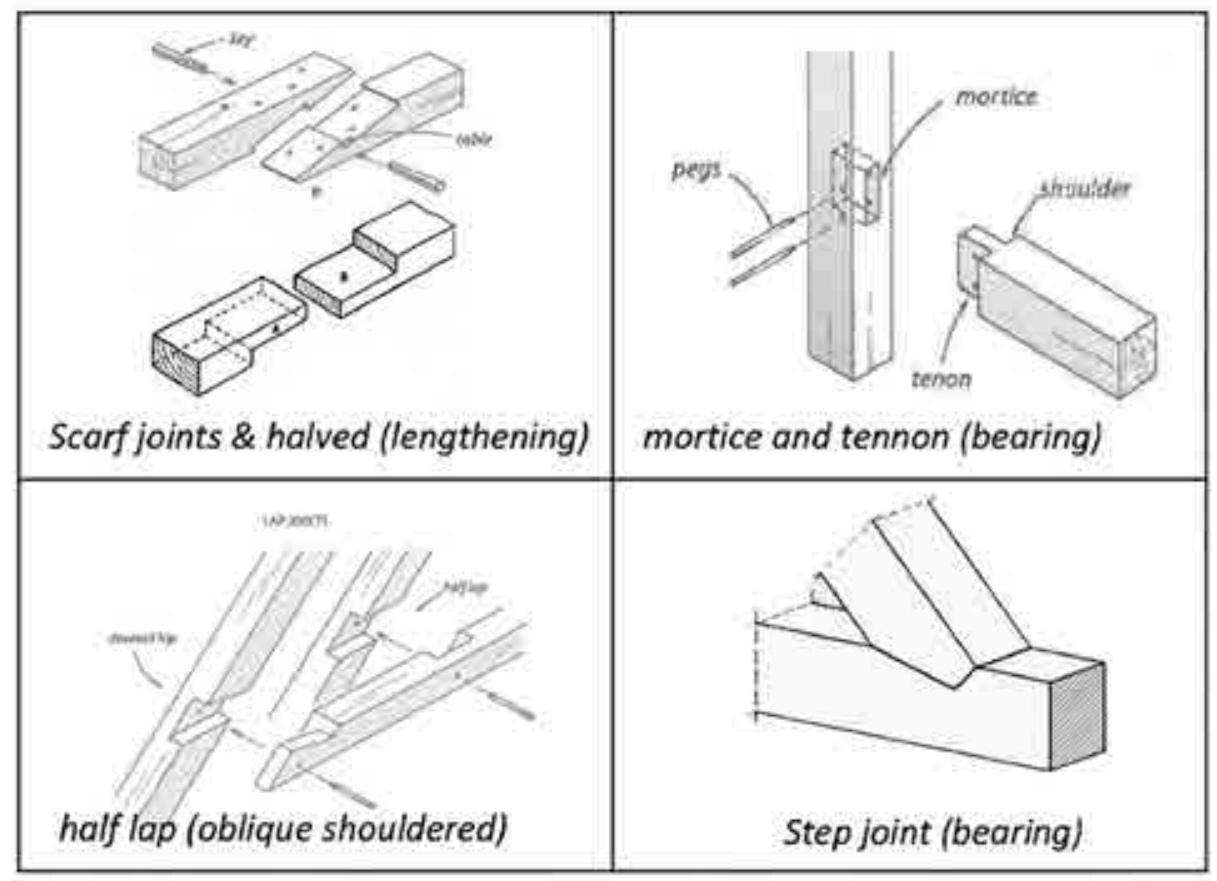

In the oldest structures, the presence of half lap joints is the most diffused both in the frame and in the roof structures. The halving is sometimes fashioned as decorative element, and can assume different forms; for example, through the dowetail form and with the contribution of the wooden pegs, the connection can bear not only compression forces, but also small amounts of tension forces. These joints presented the advantage of an easy shaping; on the other side, such connections cause an internal eccentricity in the transmission of forces among structural members, and in case of weather-exposed connections, there is risk of deformation of the half lap with consequent not-adherence with the adjacent structural member, and consequent failure (Perria, Paradiso, Kessel, Sieder, 2016).
Figure 33. Example of queen post truss Source: Author's files.
Figure 34. Most diffused connection families in the half-timber structures Source: Author's files. 
Figure 35. Historical evolution of the connections in the wall frame Source: Author's files.
From the XVI century, under the French influence, the mortise and tennon slowly replaced the halved connections both in the frame and roof structures. It became the most diffused connection presents in a big variety of forms, used to connect mainly perpendicular but also diagonal timbers in the wall frames. The use of the mortise and tennon, permits to bear only compression forces. The morticed connection could also bear very small amount of tension forces thanks to the resistance to the withdrawal that the joint assumed with the wooden pegs. In the connection between tie beam and rafter, in the rafter roof, the combination lap-dovetail joint, mortise and tennon joint were succeeding one after the other during the evolution if the truss-framed buildings from the XIII century onwards. The same evolution of the connections is present in the wall frames (Figure 35).

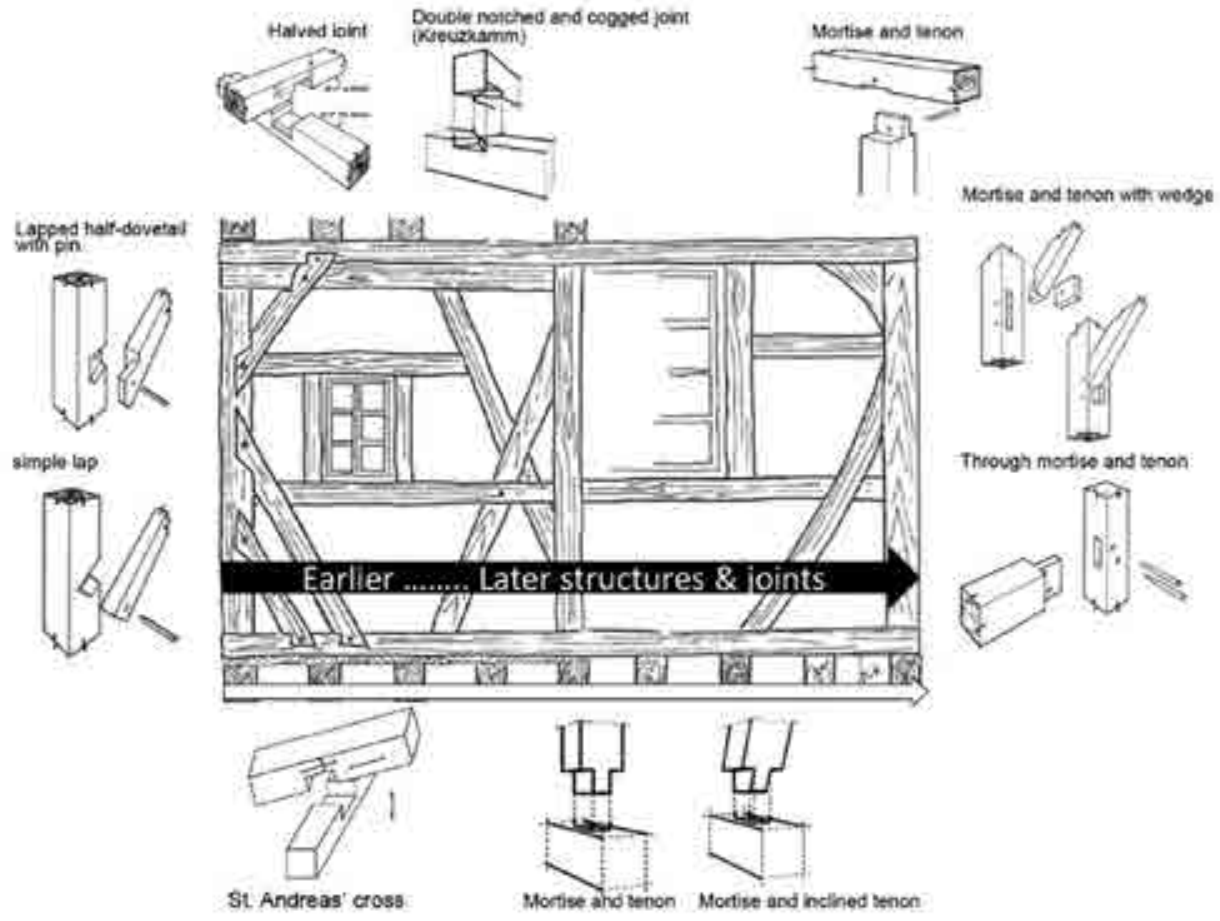

Scarf joints are used to elongate beams, plate and purlins. Various forms of scarf were developed to suit the directions of forces acting on them, among the most diffused there are the halved joint or half-wood, the halved undersquinted, the halved and tabled, stop-splayed and undersquinted joint (Gerber joint) and the most elaborated Splayed undersquinted and tabled scarf joint with (or without) key (Figure 36).

The step joint (Figure 37) is present above all on in the forms of step joint, double step joint, skewed tennon joint and heel joint. The step joint with its variants replaced in later structures, aboveall in roof trusses of purlin roofs the connection of the main rafters at the ridge and the connetion between the tie-beam and the main rafters.

The entire joint's categories are traditionally assembled without any kind of mechanical fasteners; on the other side, to prevent the shifting of the connection as a consequence of structural deformations, the presence of mechanical fasteners like wedges, wooden pegs or, in more recent times, wooden dowels is also very diffused.

The most common mechanical fasteners are the pegs; they are wooden elements usually slight tapered, typically I8-22 mm in section and roughly polygonal. Using a system called draw-boring the hole for the peg in the side of the mortise was slightly off-set on the tennon 
so that when the peg was finally driven through, the whole joint tightened up. Pegs are used in joints that have to resist withdrawal. In Europe, pegs were most made of hardwood like oak, even when the frame elements are in softwood.

The wooden dowels are used in the same way as the wooden pegs but have cylindrical form. These were used in the latest structures when the cutting techniques of wood evolved and permitted to shape more exact holes, and the correspondent dowels. The key or wedge is formed by two V-shaped blocks (wedges) that are forced into the space between the two pieces (tabling), and have the role to pre-compress the joint and ensure the adherence between the facing contact surfaces.
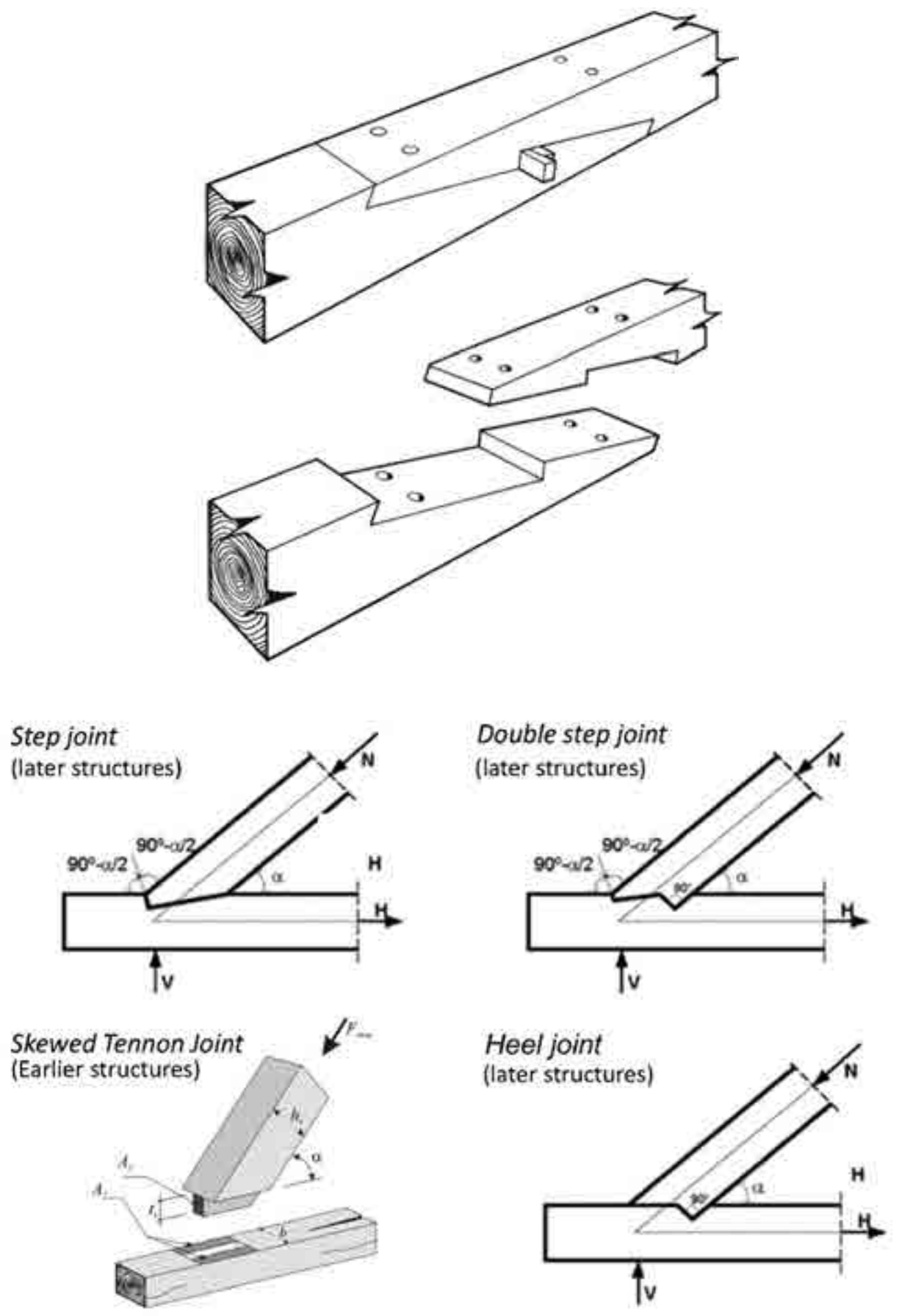

Figure 36. Splayed under squinted and tabled scarf joint with (or without) key Source: Sobon, 2002

Figure 37. Different variants of step joint Source: Author's files. 


\section{Finishing systems}

The exterior finishing of half-timber structures is made weather tight in various way. On the Continent, the opening in between the frame, the infill panels, are generally filled with rubble and plaster (Figure 38), with brick (Figure 39) or with wattle-and-daub (Figure 40). The wooden framework is left exposed to form a pattern between the infill. The filling with watt-and-daub was the most diffused until the I6th century. In this century, both for durability and economical reasons it was replaced by a bricks infill. The panels were finally left in view, or plastered with clay. In countries were the lumber was abundant, the wood-frame had a wood sheeting called weatherboards or timber lathing covered by plaster finishing. Lathing or boards have also a structural function of increasing the stiffness of the timber structure working as a diaphragm.

With the evolution of the technique, in places where the stones were abundant, thin natural stone slab from native rock, which is split into thin layers were used as a roof covering or wall cladding was used. This roof covering from inorganic material was not just a protection against the weather but also worked as fireproof material (Figure 4I).

\section{EXPANSION TO THE AMERICAS}

During the colonization of the Americas, the European constructive methods present in the colonizing countries were exported over the Ocean. In North America, examples of half-timbered structures are in New Orleans, while the French Colombage was exported to Mississippi (Poletti, 20I3), and in Haiti, where the architectural elements of the Gingerbread houses were adapted to the tropical climate. In Central America, the timber frame structures were also exported from the French and Spanish crowns during the establishment of representatives buildings in the new towns.

The Colombage (Figure 42) is a timber-frame filled with brick and diagonals at the angles. The wood, with carved shapes, adorns façades and roof banks, high ceilings and large openings onto vast porches. The second version of the houses is the braced timber-frame clad with horizontal lapped-wood siding on the exterior, also known as shiplap siding. The

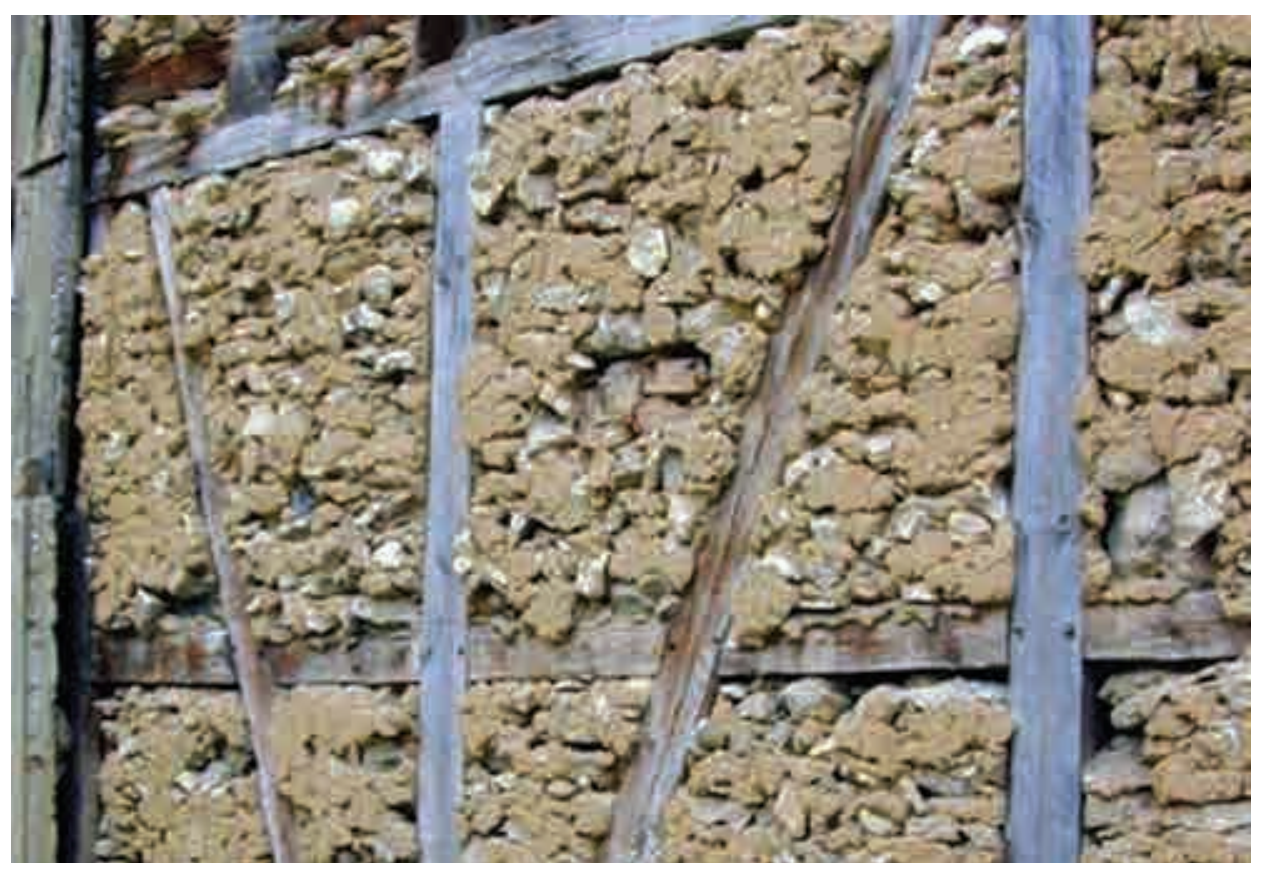



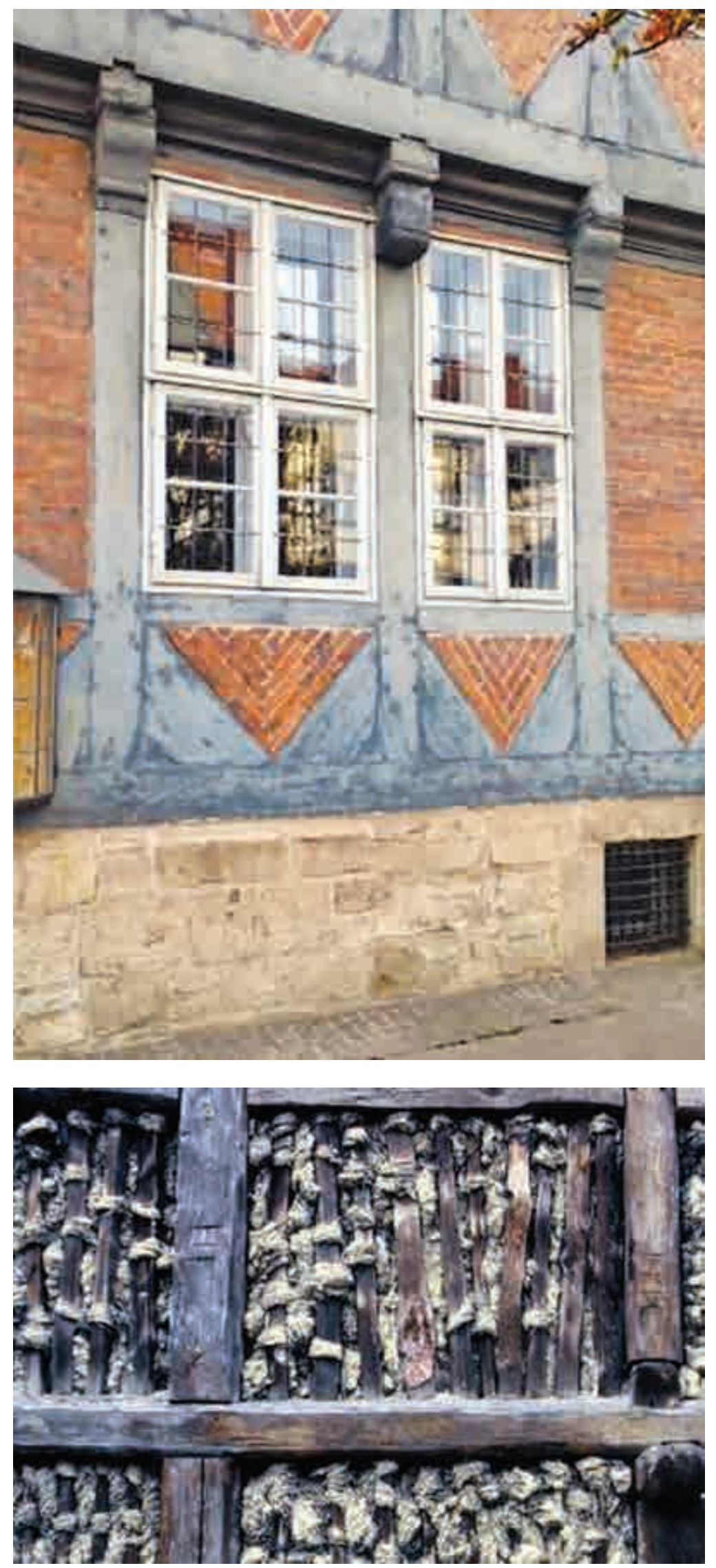

Figure 39. Infill with bricks Source: Elena Perria, 2017. 
Figure 4I. Wall cladding with natural slate stone in Goslar

Source: Elena Perria, 2016
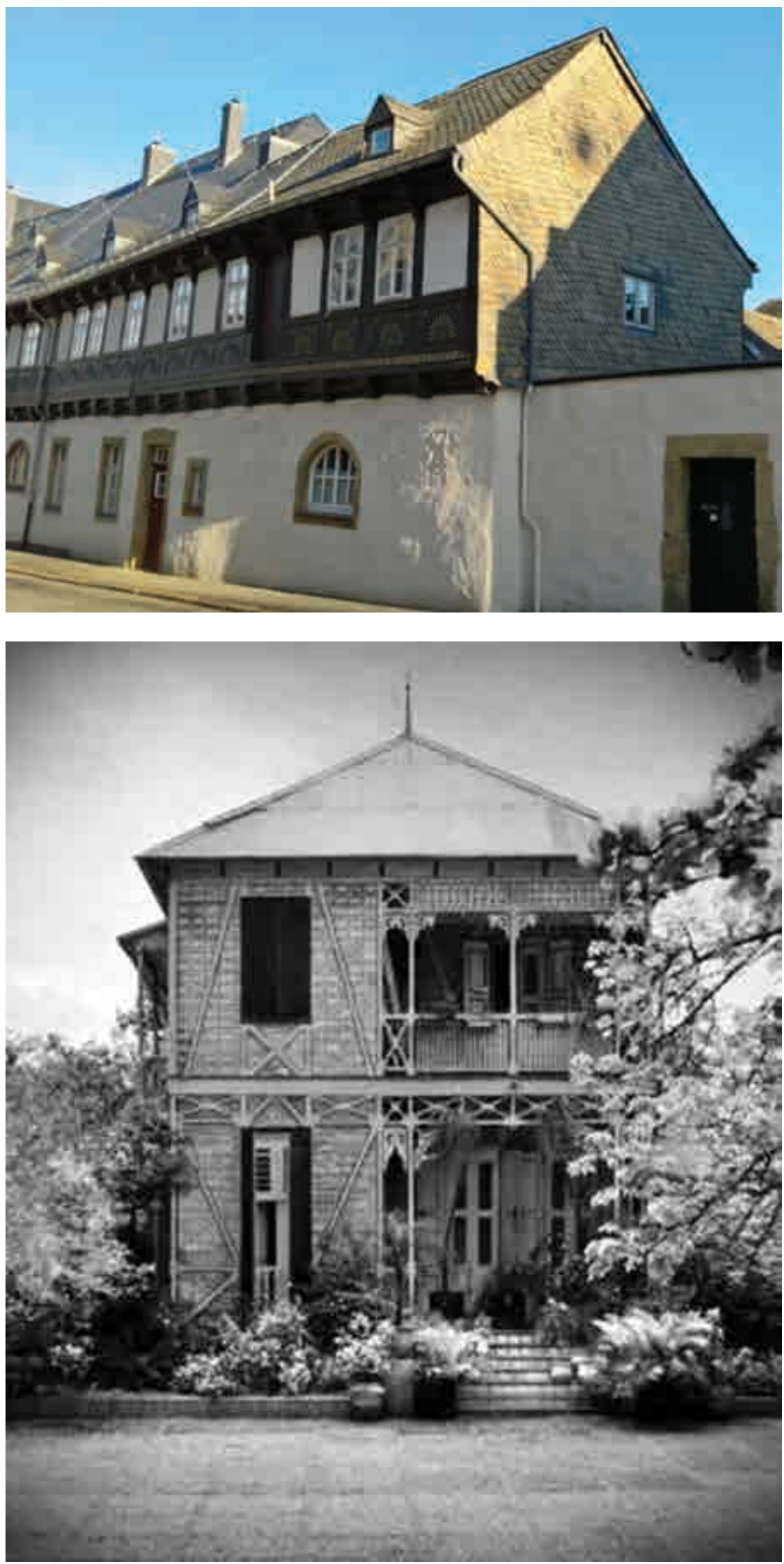
Gingerbread houses are designed to take advantage of ventilation and shade, and exclude moisture. Large windows and doors allow for cross breezes. Tall ceilings and large attics with ventilators allow hot air to rise, collect, and be expelled. Deep porches that extend from the front façade to the side walls provide shading for the windows and allow the living space to extend outside the walls of the house (Avrami, 20I0).

In the Spanish Caribbean area and South America, the most diffused technique before the IV Century was the Bahareque technique. The Bahareque construction (Figure 43) is a post and lintel system, composed of vertical and horizontal wooden elements combined with specific type of unions to form a collaborative frame with tightening function.

The filling materials are intertwined branches (wood fibers, bamboo or coconut fibers) covered with fragmented stone material and bonded with lime mortar and plaster, the so-called cuje walls. When the Spanish imported their European expertise, the native technique a new constructional system was implemented: the Colonial system. The Colonial architecture (Figures 44, 45) was the commingling of the imported Spanish-Arabic Mudéjar architecture (Figure 46), common in the southern part of the lberian peninsula, and the Bahareque, the local autochthonous constructional technique. The Colonial system is also a post and lintel system.

The horcónes, the load-bearing pile foundations, are individual poles or groups of wooden poles (depending from the dimension of the structure) that from the ground rise up to the upper edge beams of the roof. They have squared cross-section or also a raw form with variable and irregular circular section. This self-bearing timber structure is culminated with the typically colonial roof cubierta de par y nudillo structure (Nuere, 2003). Inspired by the Mudéjar system and the naval engineering, it has a reverse boat frame shaped form (Figure 47). The horizontal and vertical elements are connected with carpentry wood-wood connections from the European tradition (Figure 48). The wooden structure is drown into masonry or brick walls (Figure 49).

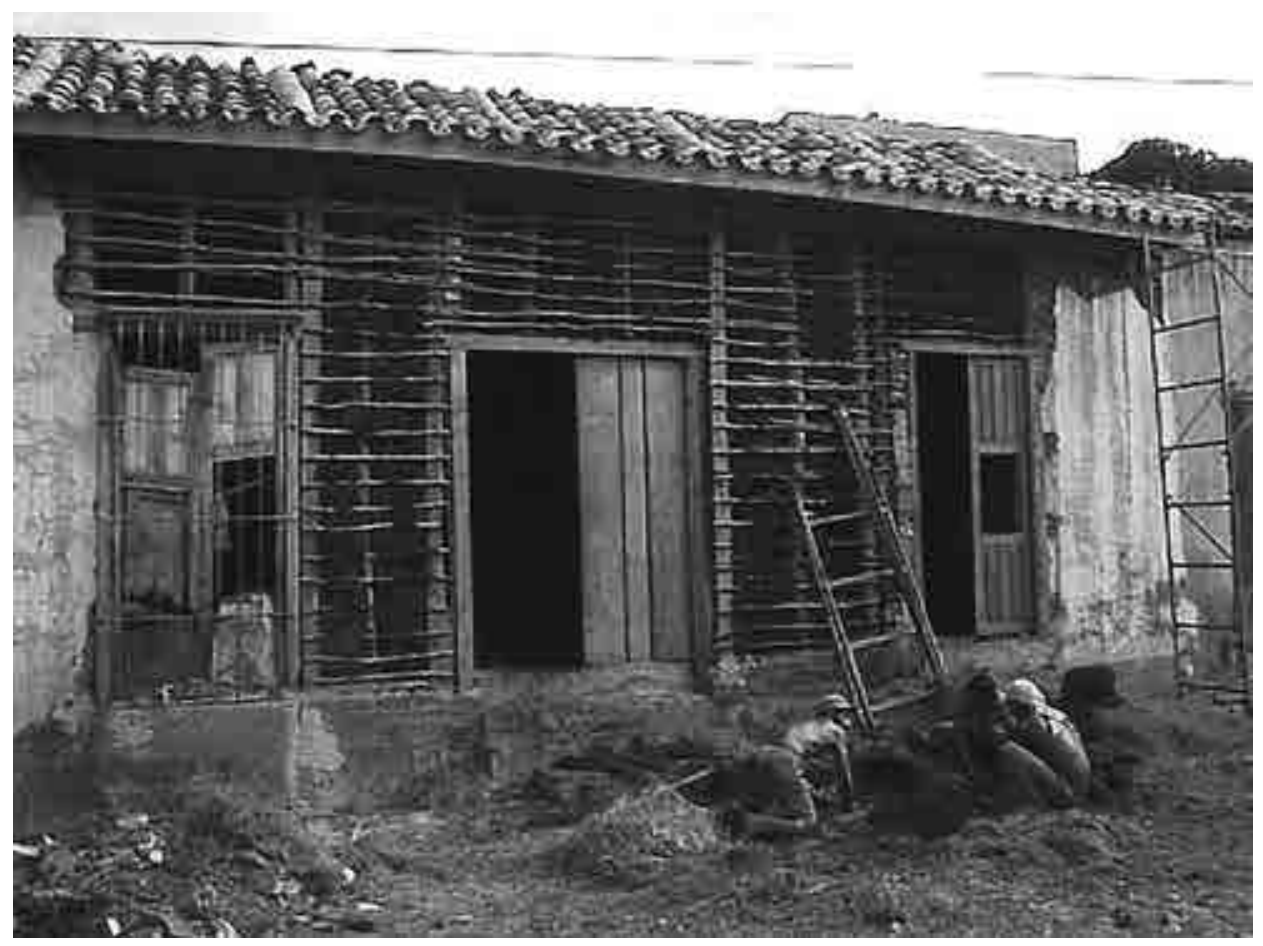

Figure 43. Structure in bahareque technique Source: Revista de la Construcción, 2010. 
Figure 44. Typical Colonial building. Calle San Jerónimo, Santiago de Cuba, Cuba Source: Elena Perria, 2010.

Figure 45. Typical Colonial building. La Casona, Santiago de Cuba, Cuba

Source: Elena Perria, 2010

Figure 46. Mudéjar architecture in the Santo Eulalia Church in Totana, Murcia

Source: $h t$ ttps://commons.wikimedia.org/w/ index.php?curid $=35688956$
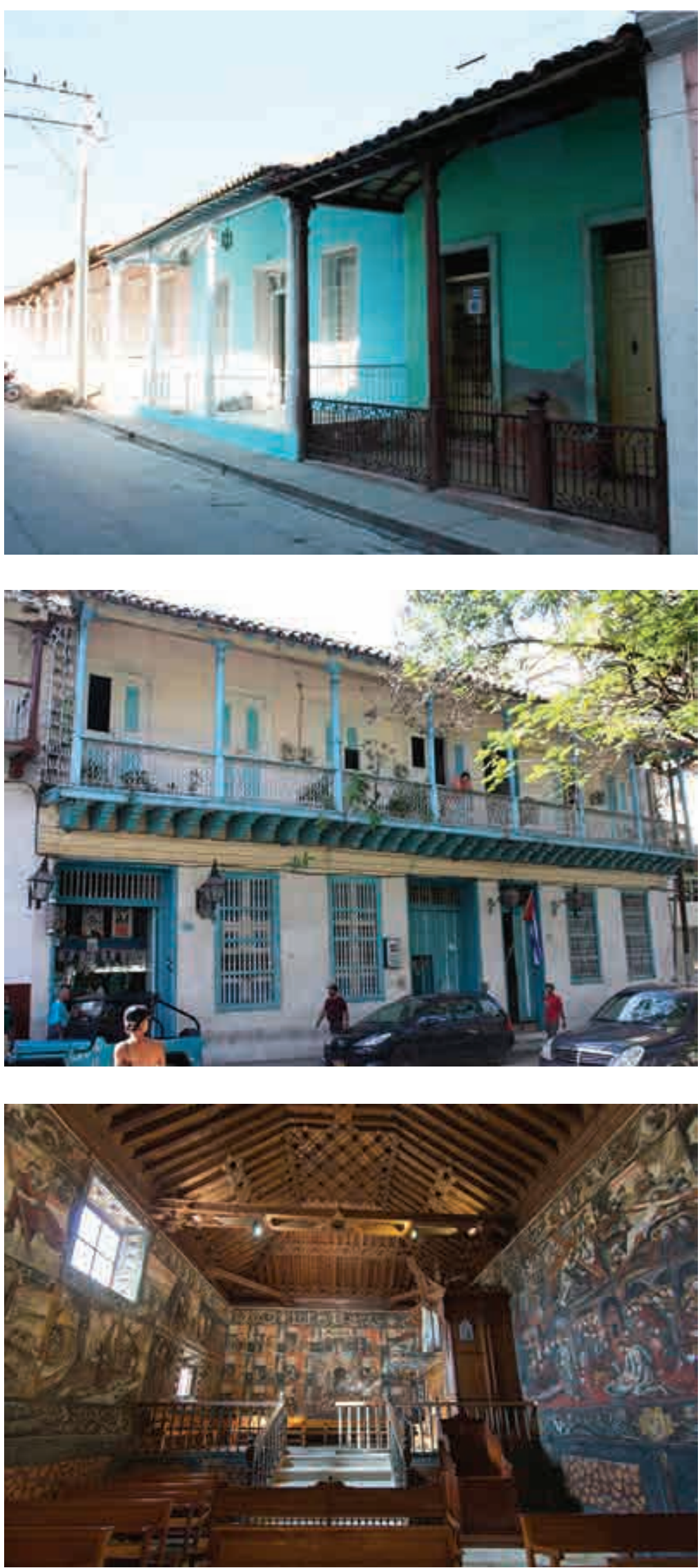

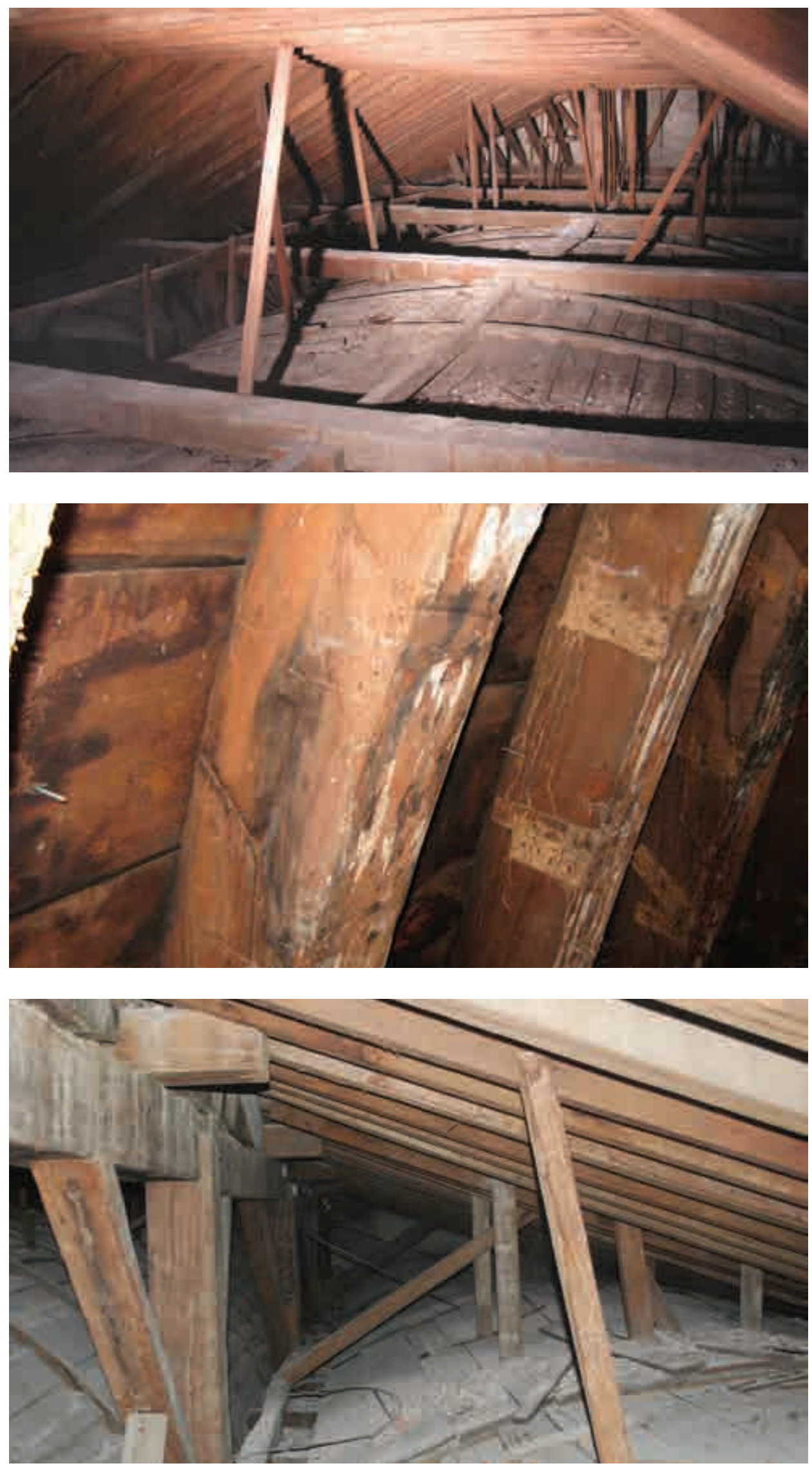

Figure 47. Typical Colonial Roof structure. Cathedral of Santiago de Cuba, Cuba Source: Elena Perria, 2010.

Figure 48. Jupiter joint or Splayed undersquinted and tabled scarf joint with key of the wooden dome of Santiago de Cuba's Cathedral, Cuba

Source: Roncoli, 2013
Figure 49. Wooden structure of Santiago de Cuba's Cathedral drown into masonry and brick walls

Source: Elena Perria, 2010. 


\section{CONCLUSIONS}

The term half-timber does not describe a style but many of structural systems. The halftimbered structures are composed by a wooden skeleton, where the vertical and horizontal structural elements enclose compartments with not load-bearing infill materials.

The evolution of the thousands of existing constructional techniques with timber returns on the constant attempt to increase their stability, needs of the evolving society, and finally the advent of the industrialization and contemporary era. Their evolution along the history have been always characterized by the refinement of foundations, connections, diagonal and longitudinal bracing and roof systems.

From an historical point of view, many constructional methods developed along the centuries from the Middle East to Europe and then to America. Timber constructional techniques originally developed in Middle East countries, evolved in Europe focusing on different challenges connected to the region. On one side, in continental and northern Europe the focus was to improve the lack of stability and durability due to the wet climate; on the other side, in the European southern countries structures needed to be improved against frequent earthquakes. With the colonial expansion, Spain, United Kingdom, and France, exported their "national techniques" in their colonies. The integration of the "western" techniques with the indigenous ones brought to the implementation of the colonial systems with peculiar stylistic and constructive characteristics that also here adapted to different climatic and living conditions. With the beginning of the industrialization era (I850), the wooden construction lost their attractivity and were replaced by others construction materials. The reborn of the wooden era was introduced by the development of contemporary engineered wood materials that permitted the development of new timber structural techniques; among them, the platform timber construction, prefabricated timber panels construction, glulam high span structures, and massive wooden constructions.

As a conclusion, the half-timber and timber frame structures are spread over the time, all over the world, and in many different regional variations.

\section{REFERENCES}

Ashurst, J., Ashurst, N. (20I2). English heritage. Practical building conservation: TIMBER. Ashgate.

Avrami, E. (2010). Preserving Haiti's Gingerbread Houses 2010 Earthquake Mission Report. World Monuments Fund, New York.

Cóias, V. (2007). Structural rehabilitation of ancient buildings (in Portuguese). Lisbon: Argumentum, GECoPRA.

Gatzelu, D. (1899). Carpintería de armar. Madrid.

Gerner, M. (1983). Fachwerk: Entwicklung, Gefüge, Instandsetzung. Deutsche VerlagsAntstalt, Stuttgard.

Gerner, M. (1990). Historische Häuser erhalten und instandsetzen. Augustus Verlag, 2. Aufl. S.I31-132.

Holzer, S. (2015). Statische Beurteilung historischer Tragwerke Band 2, Holzkonstruktionen. Ernst \& Sohn, Berlin, Germany. 
Informationsdienst Holz. (I 2/2004). Erneuerung von Fachwerkbauten, Holzbau Handbuch.

Langenbach, R. (2006). Saga of the Half-timbered Skyscraper: What Does Half-Timbered Construction have to do with the Chicago Frame? In: Proceedings of the Second International Congress on Construction History, Cambridge University.

Langenbach, R. (2010). Preserving Haiti's Gingerbread Houses: 2010 Earthquake Mission Report. World Monument Found, WMF, New York. (Norma Barbacci, ed.).

Langenbach, R. (20I3). Timber Frames and Solid Walls: Earthquake Resilient Construction from Roman Times to the Origins of the Modern Skyscraper. Hearth 2013 Proceedings.

Makarios, T., \& Demosthenous, M. (2006). Seismic Response of traditional buildings of Lefkas Island, Greece. Engineering Structures, 28(2), 264-278.

Morcate, F. et al. (1990). El sistema constructivo colonial. Santiago de Cuba: Onelia Martínez Capetillo.

Nebel, H. (1978). Erneuerung von Fachwerkbauten in: INFORMATIONSDIENST HOLZ. EGHBericht, 2. verbesserte Auflage. München.

Nuere, E. (2003). La carpintería de armar española. Munilla-Lería.

Paradiso, M., Milani, P. et al. (20I I). Atlas del patrimonio arquitectónico y cultural del casco histórico de Santiago de Cuba. Edición Medina, Borgo San Lorenzo.

Paradiso, M., Perria, E. et al. (2013). La Catedral de Santiago de Cuba como ejemplo emblemático de la difusión de saberes entre Europa y Latino-América. En CNHC - Congreso Nacional de la Historia de la Construcción, Madrid 9 - 12 de octubre. Madrid: Ed. Instituto Juan de Herrera.

Perria, E., Paradiso, M., Kessel, M., Sieder, M. (20I6). Characterization of the halved and undersquinted scarf carpentry connection. In Proc. of WCTE 2016, World Conference on Timber Engineering, Vienna University of Technology, Grafisches zentrum HTU, Austria.

Perria, E., Paradiso, M., Kessel, M. (2016). Experimental verification of the static model for the characterization of the halved and undersquinted scarf connection. In Proc. of I0th International Conference on Structural Analysis of Historical Constructions, in press, Leuven, Belgium.

Poletti, E. (2013). Characterization of the seismic behaviour of traditional timber frame walls. Tese de Doutoramento, Universida do Minho.

Revista de la Construcción 9(I), 89-97, 2010, agosto. Recuperado de http://dx.doi. org/10.4067/S0718915X2010000100010

Ruggieri, N. (20 I 3). I/ sistema antisismico borbonico muratura con intelaiatura lignea genesi e sviluppo in Calabria alla fi-ne del '700. Bollettino ingegneri, No. 10, pp. 3-14.

Sánchez, F., De Julián, J. J., Ordóñez, A. (2010). Constructive Typologies in a Patrimony City: Trinidad, Cuba. Revista de la Construcción, 9(I).

Sobon, J. A. (2002). Historic American Timber Joinery: A Graphic Guide. Pub. By Timber Framers Guild, Ed. by Kenneth Rower. Retrived from https://www.ncptt.nps.gov/wpcontent/uploads/2004-08.pdf. 
Touliatos, P. (2004). Evaluation and drafting of recommendations for interventions in buildings of the historical settlement of Lefkas (in Greek). Organization for seismic design and protection. Athens, Greece: Public Library of Lefkas Editions.

University of the West of England - UWE. (2008). Traditional Timber Framing. A Brief Introduction. From: https://fet.uwe.ac.uk/conweb/house_ages/timber/print.htm,

Vintzileou, E., Zagkotsis, A., Repapis, C., \& Zeris, Ch. (2007). Seismic behavior of the historical structural system of the island of Lefkada. Construction \& Building Materials, 2I(I), 225-236. Greece.

Vivenzio, G. ( I 783). Storia e teoria de' tremuoti in generale ed in particolare di quelli della Calabria, e di Messina del I 783. Napoli: Stamperia Regale.

Weiss, J. E. (1979). La arquitectura colonial cubana: siglos XVI al XIX. Ciudad de La Habana: Editorial Letras Cubanas. 